\title{
Biodiversity and Complexity of Rice Farm Ecosystems: An Empirical Assessment
}

\author{
Debal Deb ${ }^{*}$
}

Centre for Interdisciplinary Studies, Barrackpore, Kolkata 700123, India

\begin{abstract}
Modern rice farms are characterized by the use of synthetic agrochemicals, which eliminate a large segment of biodiversity on-farm. In contrast, organic rice farms tend to preserve much of natural biodiversity. While biodiversityproductivity relationship in organic $v s$. chemicalised rice farms is contested, the relationship of on-farm biodiversity with food web structural properties and ecosystem services remains to be explored. To understand the functional significance of species richness and ecosystem complexity of rice farms, I examine here the architectural properties of rice food webs from West Bengal, based on replicated plots of folk variety (organic) and modern (chemicalised) rice systems. All rice food webs, constructed from observational data collected over three years, show prominent scale dependence of dietary links, link density, web height, diversity of natural enemies to pests, predator-pest ratio, and the numbers of omnivores and omnivory levels. Organic folk rice webs tend to have greater mean species richness, predator diversity, predator-pest ratio and chain length than modern rice farm webs, yet both systems show homogeneity of distribution of the web properties. Analyses of 16,400 computerized analog webs, following non-random rules of species association drawn on real-life, seasonally distinct rice food webs, validate the robustness of conclusions.
\end{abstract}

Keywords: Agroecosystem, complexity, ecolosystem services, food web, omnivory, pest control, predation, rice, west Bengal.

\section{ECOLOGICAL COMPLEXITY OF RICE FARMS: AN EMPIRICAL ASSESSMENT}

\section{Introduction}

Beginning in the late 1960 s, the Green Revolution has intensified agricultural production in India by replacing local crop diversity with monocultures of modern crop varieties that are highly responsive to synthetic fertilizers. The cultivation of these high input-responsive varieties necessitates application of increasing amounts of agrochemicals, leading to enhanced environmental degradation and reliance on high capital and production inputs (Tilman 1998; Matson et al. 1997; Tilman et al. 2002). On most farms of South Asia, monocultures of rice have abrogated traditional multiple cropping systems, thereby drastically truncating crop diversity as well as rice genetic diversity on-farm (Dwivedy 1997; Deb 2004). On-farm biodiversity is further eroded by the escalating use of insecticides, fungicides and herbicides (Stark and Banks 2002; Relyea 2006; Costa et al. 2008).

In contrast, traditional, pre-industrial mode of ecological agriculture maintains considerably greater taxic and genetic diversity on-farm than modern monocultures (Clawson 1985; Dwivedy 1997). Traditional ecological agriculture employs low energy input, and does not use synthetic agrochemicals (Pimentel et al. 2005; Pearson 2007). Such ecologicallyoriented, 'organic' agriculture persists in a large number of

*Address correspondence to this author at the Centre for Interdisciplinary Studies, Barrackpore, Kolkata 700123, India; Tel: (510) 6423608 (O), 664 2731 (R); Fax: (510) 643 5793; E-mail: cintdis@hotmail.com

Handling Editor: Hideyuki Doi small and marginal farms in South Asia, chiefly because the indigenous marginal farmers are too poor to afford expensive modern variety seeds, irrigation and agrochemicals (FAO 1997; Deb 2004).

Research in agroecosystem structure and function indicate that low-external input, organic agriculture is more species-rich than the modern farming system reliant on synthetic agrochemicals (Leaky 1999; Matson et al. 1997; Mäder et al. 2002; Tilman et al. 2006). However, to understand the dynamic relationship between species composition and agroecosystem structure, a detailed food web structural analysis is warranted. Until the late 1990s, agroecosystems have seldom been included in food web studies, on the presumption that their structural properties may not reflect natural food web architecture. Indeed, "many ecologists are unfamiliar with the numerous, well-replicated experiments comparing agricultural diversity and simplicity" (Pimm 1997: 127), although agroecological studies provide enough insights into the different properties of agroecosystems. A few recent studies have recorded the effects of pesticides on food chain length by species elimination in modern chemicalised rice farms, and yielded valuable data about the imperfection of pest control (Heong and Schoenly 1998; Heong et al. 2007). However, there is paucity of studies to relate rice field food web properties to agroecosystem functions and services. In view of the global importance of rice as the staple crop in more than 100 countries, and that $96 \%$ of rice is produced and consumed in developing countries (Hossain and Narciso 2004), it is necessary to understand the linkages between rice farm ecosystem functions and production. This understanding is incumbent on a detailed description of the rice farm food web. In this work, I attempt to describe the rice farm food web structure based on a large 
set of seasonal data of biodiversity associated with different rice varieties. Subsequently, I build a large sample of computerized analogs of the empirical food webs in order to achieve robustness of conclusions about the observed architectural properties.

\section{Materials and Methods}

\subsection{Study Sites and Design}

The field study was conducted on the research farm of the Centre for Interdisciplinary Studies (CIS), for three years (from the year 2002 to 2004) at Binodbati village in Bankura district, West Bengal, where over 500 different traditional rice varieties are grown each year. On this farm, 14 plots of indigenous (folk) rice varieties and two plots of modern rice varieties were selected for examination of their food web structures. The size of each plot was $2 \mathrm{~m} \times 2 \mathrm{~m}$, spaced $\geq 3$ $\mathrm{m}$ apart from its nearest neighbouring plot. The organic plots sown with folk varieties (FV) received zero agrochemical inputs, whereas the chemicalised modern variety (MV) plots grew MTU 7029 on conventional doses of synthetic chemical fertilizers and pesticides. The rationale of growing MTU 7029 on the chemicalised plot is that this modern variety is the most popular among all chemical farmers in the region. Each plot contained a uniform density of 100 rice hills, with a uniform spacing of $20 \mathrm{~cm}$ between neighboring hills. Within a few weeks after transplanting, each hill developed multiple tillers (numbering 6 to 20, depending on the variety) of rice plants.

Until acquisition by CIS in 2001, the farm had been subjected, over the past 12 years, to treatments with cattle manure, supplemented by moderate dosage $(25-35 \mathrm{~kg} / \mathrm{ha})$ of synthetic fertilizers, chiefly urea, but no pesticides. The ratio of cow dung to synthetic fertilizers was around 3:1. Upon acquisition in 2001, the land was thoroughly plowed, and was treated with cattle manure and green mulch. All farm plots were sown to FVs, treated with organic manures and green mulch, and zero pesticides. Companion crops like pigenpea (Cajanus cajan) and rozelle (Hibiscus sabdariffa) were also cultivated, following traditional practices, on the FV farm margins, but not on MV farm margins. Non-crop grasses and broadleaves appearing on the FV farms were removed manually, but 'de-weeding' was withheld after the onset of flowering of the rice plant. In contrast, a corner of the farm $(10 \mathrm{~m} \times 10 \mathrm{~m})$, separated by a ridge from the rest of the farm, were sown to modern variety (MV) rice, and treated with synthetic fertilizers, pesticides and glyphosate herbicide, following conventional practice and recommended dosage (Gill 1995; Aulach et al. 2000; Monsanto Co. 2009). After the rice harvest in winter every year, all farm plots were sown to mustard, with no agrochemical inputs.

Data on biodiversity of all these farm plots were collected in the years 2002, 2003 and 2004 during rice cultivation seasons. All above-ground macroflora and fauna occurring in all farm plots were recorded during the preflowering $(\mathrm{PF}), 50 \%$ flowering $(\mathrm{F})$, and circa-harvesting phases $(\mathrm{H})$ of the rice plant. During each phase, biodiversity was assessed on 2 consecutive days, and on each day, 3 times with 4-hr durations. The data from each day's record of biodiversity over the 2 days during each life-history stage were pooled to depict a repertoire of species associated to each farm plot. A food web was constructed for each plot, based on food linkages between the organisms recorded on that plot during each of the three phases of the rice plant's life, pooled over three years. Thus, we constructed 42 webs from the $14 \mathrm{FV}$ plots, and 6 webs from the $2 \mathrm{MV}$ plots.

Because of intensive sampling of organisms during each phase, the cumulative number of species rarely exceeded after the second year, and the species composition remained largely unchanged. Table 1 illustrates the cumulative species counts for a FV and MV rice plot for three consecutive years, and this pattern is generally repeated for all rice plots. In order to avoid confounding of sampling effort with treatments, I pooled the species diversity data for each phase of rice plant's life over three years. The pooling of all counts of species occurring at each phase of rice on each rice plot over 3 years thus yields the maximal species count in 3 years, but separates the effects of three different phases of the rice plant.

Table 1. Cumulative Species Counts from a FV (Ashu) and MV (MTU 7029) Plot

\begin{tabular}{|c|c|c|c|c|c|c|}
\hline \multirow{2}{*}{\begin{tabular}{|c|c|c|c|}
$|c|$ \\
Phase
\end{tabular}} & \multicolumn{2}{|c|}{} & \multicolumn{2}{c|}{2003} & \multicolumn{2}{c|}{2004} \\
\cline { 2 - 8 } & Ashu & $\begin{array}{c}\text { MTU } \\
7029\end{array}$ & Ashu & $\begin{array}{c}\text { MTU } \\
7029\end{array}$ & Ashu & $\begin{array}{c}\text { MTU } \\
7029\end{array}$ \\
\hline \hline PF & 41 & 22 & 44 & 24 & 44 & 24 \\
\hline F & 27 & 31 & 28 & 31 & 28 & 32 \\
\hline H & 40 & 25 & 41 & 25 & 41 & 25 \\
\hline
\end{tabular}

All species sighted in each rice plot were recorded to construct a disparate seasonal food web. The data variables for all food web matrices $W_{\mathrm{ij}}$, are given in Table $\mathbf{2}$, where $i$ is the life history stage of the rice plant, and $j$ is the cultivar of rice.

Each seasonal web $W_{\mathrm{ij}}$ for a rice plot represents a distinct spatial and temporal segment of the overall rice farm ecosystem, reflecting the presence or absence of organisms on a cultivar plot at different times of the rice growing season. All above-ground flora and fauna on each plot were recorded during the rice growing season, June to December each year. Owing to lack of taxonomic expertise, belowground biota, excepting earthworms, were excluded from the web analysis. During the wet season, algae, zooplankton and aquatic insects were also included in the food web data base. Algae, Cladocera and rotifer zooplankton were lumped as separate guilds, and treated as trophospecies, while relevant life history stages of aquatic insects, fish and frogs were separately identified as distinct 'ontospecies' (ontologically distinct element in the food web, with characteristic trophic relationships). The total number of ontospecies $(S)$ comprises the size of a food web.

An aggregate rice food web $\left(W_{\text {sum }}\right)$ was constructed by assembling all the ontospecies recorded from all the seasonal FV food webs $W_{\text {ij }}$ (Appendix A). The cumulative number of component species in the $W_{\text {sum }}$ thus sets the theoretical upper 
Table 2. Descriptors for Constructing Rice Food Webs $W_{\mathrm{ij}}$

\begin{tabular}{|c|c|c|}
\hline Life History Stage of Rice Plant (i) & Farm Type (j) & Rice Cultivars \\
\hline Pre-flowering (PF) & \multirow{3}{*}{$\begin{array}{l}\text { Folk Variety (FV) Farm } \\
\text { (with zero-chemical inputs) }\end{array}$} & $\begin{array}{l}\text { Ashu, Asanleya, Bahurupi, Bhutmoori, Chakramala, Deulabhog, Jhinga-sal, Jugal, } \\
\text { Kabiraj-sal, Kelas, Lata-sal, Malabati, Nata, Rup-sal, Sada jira, Tulsi mukul }\end{array}$ \\
\hline $50 \%$ Flowering $(\mathrm{F})$ & & All 14 varieties \\
\hline Harvesting $(\mathrm{H})$ & & All 14 varieties \\
\hline Pre-flowering (PF) & \multirow{2}{*}{$\begin{array}{l}\text { Modern Variety (MV) Farm } \\
\text { with synthetic agrochemicals } \\
\text { inputs }\end{array}$} & MTU 7029 \\
\hline Harvesting $(\mathrm{H})$ & & MTU 7029 \\
\hline
\end{tabular}

limit of the range of food web size $(S)$ for both FV and MV webs.

\subsection{Estimation of Food Web Properties}

i) Gut content analysis (GCA) was not performed, on the understanding that even the established dietary links are always in a state of flux, and that inferences from GCA of small samples examined at any period would be necessarily inconclusive (Deb 1997; Gunnarsson 2008). Currently available knowledge about the presence/ absence of dietary links between ontospecies seems to be sufficient for the purpose of describing the communities - the primary objective of constructing food webs. Food linkage data were gathered from published literature, farmers' experience, and direct observation of predation acts. The complete list of publications consulted for determining food links in this study is too large to cite here. A list of representative citations used here to enumerate preypredator links is given in Appendix B.

ii) While unevenly resolved categories of plant material as basal ontospecies (Goldwasser and Roughgarden 1993) may lead to conflicting inferences about food web properties, finer resolution of basal components is useful to generate statistically robust generalizations. Thus, "pollen and nectar", "plant sap", "leaves" and "seeds/grains" are included in this study as distinct basal components to describe the disparate routes of energy flow from plants to mutualists (bees and adult Lepidoptera) and different herbivores that feed on the rice plant parts (e.g. lepidopteran pest larvae, gundhi bug, snails, hoppers, graminivore birds). Detrital food chain is incorporated into the community matrix by including "soil \& detritus" as an ontospecies.

iii) Cohorts of species with similar food habits and predators have not been lumped into what Briand and Cohen (1984) called "trophospecies". Rather, each species are separately identified. Relevant life history stages of life history omnivores and intraguild predators have been separated to identify disparate trophic links. Likewise, the problem of describing predation cycles (e.g., A eats B, B eats A) is precluded by identifying each relevant life history stages are as a distinct ontospecies. iv) Several conventions are followed here to describe the food web properties. Top species have prey but no predators. Intermediate species have both prey and predators. Basal species (BAS) have consumers but no prey. Trophic omnivores feed from more than one trophic level. Chain length is the length of the path from the basal to the top trophic level in the food web. Thus, a food web with $n$ trophic levels has the longest food chain of $n-1$ links. The longest chain length is the web height (WH).

v) Empirical studies as well as computer models suggest that omnivory links to non-adjacent trophic levels are more common in natural food webs than predicted by theory (Rosenheim and Corbett 2003; Williams and Martinez 2004; Duffy et al. 2007). To examine the robustness of this assumption, 8 possible levels of omnivory (OL) are described here (Table 3 ).

Table 3. Levels of Omnivory

\begin{tabular}{|c|c|}
\hline Omnivory Level (OL) & Trophic Levels of Prey \\
\hline \hline 1 & BAS + INT(1) \\
\hline 2 & BAS + INT(1) +1 higher level \\
\hline 3 & BAS + INT( $>1)$ \\
\hline 4 & INT(1) + INT(2) \\
\hline 5 & INT(1) +2 higher levels \\
\hline 6 & INT(2) +1 higher level \\
\hline 7 & INT(2) +2 higher levels \\
\hline 8 & INT( $>2)+\geq 1$ higher level \\
\hline
\end{tabular}

vi) For each web, the following web properties are examined: the number of component (onto)species $(S)$, the number of links $(L)$, linkage density $(L / S)$, web height $(\mathrm{WH})$, the diversity of rice pest species (PT, estimated as the number of species feeding on any part of the rice plant - leaves, grains, plant sap), the number of predators on the pest (PR), the proportion of links between basal and intermediate species (IB), those between top and basal species (TB), total number of trophic level omnivores (OM), and the number of omnivory levels (OLN).

vii) The TB and IB link fractions indicate the links to all producers, and include the total herbivory links to the 
rice plant. The sum of TB and IB links (shorthanded here as TBIB) is therefore a proxy of the pest pressure on the rice plant. The ratio $\mathrm{PT} / \mathrm{PR}$ reflects the abundance of the pest organisms relative to the number of their natural enemies.

\subsection{Generating Analog Webs}

With the objective of examining the quantitative web properties for a large number of systems with non-random species association rules identical to those observed in the rice farms, 16,400 randomized web matrices, analogous to the farm webs, were generated on computer. In order to attain a robust statistical generalization, the size of the analog webs was made to lie on the interval $S \in(20,60)$. This range subsumes the size range of the empirical food webs $(22<S<50)$. For each $S, 400$ random iterations were generated.

To make the analog webs identical to real-life food webs, the program for generating analog webs assigned interspecific linkages in all random assemblages solely on the basis of the empirically confirmed presence or absence of dietary interactions between each pair of ontospecies (discussed above). In addition, I built into the program the following restraints:

I. In order to simulate the seasonal variation in web composition, three seasonal categories of analog webs were created: $P F$ webs (for pre-flowering phase), $F$ webs (for $50 \%$ flowering phase), and $H$ webs (for harvesting phase). This enabled selective assemblage of season-specific presence and absence of ontospecies. Thus, the hebaceous associate of rice Ludwigia parviflora and the beetle Haltica cyamea were included only in the $P F$ webs to simulate their occurrence during the late pre-flowering phase of the rice plant. Phytoplankton, rotifers, Cladocera, and their predators - crabs, mollusks, small fish and aquatic insects - were selectively programmed to "appear" in the $F$ webs simulating communities during the period from July to September. When these ontospecies occur in a web, frogs, checkered keelback, open-billed stork, and pond heron were designed to be added randomly. Rice grains, Cajanus cajan flower, the florivorous beetle Mylabris pustulata, and graminivore birds (e.g., the spotted dove, paddy field pipit and red vented bulbul) were randomly selected into $H$ webs simulating communities during the rice harvesting phase (November-December). Frogs and snakes were not incorporated in $H$ webs because they begin to hibernate in this period.

II. From the pool of 103 kinds of ontospecies (Appendix A) encountered in the rice farm communities, I programmed random selection of ontospecies to comprise each analog food web, with the nonrandom rule of seasonal assemblage (rule $I$ above). Basal ontospecies (BAS) were compsed of (i) soil and detritus, (ii) plant sap, (iii) leaf, (iv) pollen \& nectar, (v) phytoplankton, (vi) rice grain, and (vii) flowers of Ludwigia parviflora and (viii) Cajanus cajan, amongst which the first four were ubiquitously present in all rice farm food webs. Thus, the program incorporated the first four basal ontospecies into all the analog webs to simulate the real ecosystems. In contrast, following the seasonal occurrence of the other four ontospecies, I allowed random incorporation of (vi) and (viii) into the $H$ webs, and (v) and (vii) into the $P F$ webs. Furthermore, because (vii) and (viii) did not occur in MV webs, they were not included in the analogs of MV webs.

III. The records of perennial presence of selected species in the rice plots, allowed creation of a non-random pool of perennial ontospecies for FV and MV systems. For example, the common Indian myna, the black drongo and the weaver ant were recorded from both FV and MV farm plots round the year, and Calotes versicolor was recorded in all seasons on all $\mathrm{FV}$ farms, but not on MV farm plots. From this perennial species pool, the program randomly selected any (or none) of them in the analog FV and MV webs.

$I V$. Each community matrix comprised at least four basal ontospecies (see rule $I I$ ), and at least one primary consumer in order to build $\geq 2$ trophic levels in the model webs. Except for the ubiquitously occurring ontospecies (rule III), all ontospecies for each model web were randomly chosen from a non-random pool of ontospecies on all trophic levels.

The 16,400 random assemblages of the ontospecies pooled from the real-life rice farm food webs would represent a pattern of feasible species associations likely to be found in all tropical rice farms. Because a part of biodiversity is eliminated by pesticides and herbicides from the MV systems, the species assemblages of MV food webs constitute a part of the pooled FV food web components. Thus, pooling of all FV food web elements in the computerized web analogs would suffice to represent all types of rice farm ecosystems, unperturbed with toxic agrochemicals. The analog webs would therefore provide a considerably wider database of empirically feasible intact rice farm ecosystems.

\section{Program Listings}

Programs for generating the randomized analogs of the pond systems and for ascertaining their structural properties were written in QBASIC. Program listings are available free on request.

\subsection{Statistical Analysis}

The objective of the statistical analyses of the food web properties is to examine the scale dependence/ invariance of different food web properties and to understand how one structural property is related to others. Linear regression and power models were employed to describe the relationships between the different web properties; for each relationship, the model yielding the highest value of $R^{2}$ was chosen as the most appropriate model. To examine if the FV webs and MV webs belong to the same distribution, homogeneity $X^{2}$ test was performed for $S, L$ and species fractions. The significance of correlations was measured by $t$ test, at $>95 \%$ confidence limit. The significance of difference between the mean values of selected properties of FV and MV webs was determined by using $t$ test for unequal variances. 


\section{Results}

\subsection{Field Observations}

The floral biodiversity on FV and MV farms in the first week after transplanting of rice plants is given in Appendix C. In addition to the pigeon pea (Cajanus cajan), black gram (Phaseolus mungo) and akanda (Calotropis procera) planted on the FV farm margins, several wild grasses and herbaceous plants occurred as companion flora on the FV farm plots. The most common companions (with frequency $>70 \%$ ) recorded from the FV farms include Cyperus rotundus, Bacopa monnieri, Chenopodium album, Marsilea minuta, Aeschynomene indica and Ludwigia parviflora. These plants appeared to offer a food and breeding habitats for various arthropods, and serve as perches for insectivorous birds.

In contrast, the MV farms housed scant floral diversity. No companion crop was cultivated in any of the MV plots. The floral diversity was further reduced by application of glyphosate (Roundup ${ }^{\circledR}$ ) herbicide. The overall floral species diversity on MV farms was significantly less than on FV farms (Appendix C). Arthropod diversity was also less in MV plots than in the FV plots. Because the host plant diversity and micro-habitats for several arthropods in the MV plots was less than FV farms, a reduced overall occurrence of faunal diversity is expected. Although no specific experiment was conducted to find the impact of Roundup on animal taxa after its application, several insects and frogs were found to have demised on the MV farm plots. This preliminary observation corroborates findings of Relyea (2005, 2006).

The seasonal pattern of bird abundances in the rice fields indicates seasonality of prey availability. Waterbird occurrence in the study sites was largely restricted to the cultivation season (i.e. the wet season, June - September), with maximum abundance in August. Rice fields dried up during winter and supported few waterbirds except for irregular occurrences of cattle egret (Bubulcus ibis) and pond heron (Ardeola grayii). Landbird abundance increased after the start of cultivation (June to August), but more birds were attracted to the rice fields in midwinter (December to January). For both waterbirds and landbirds, most species preferred levees and fallow grass fields. Most land birds preferred to perch on the trees and shrubs bordering the farm field. A tailor bird (Orthotomus sutorius) built its nest on a mature rice hill on a FV plot in winter 2007 (Plate 1). This finding is in contrast to Maeda's (2001) report that the birds tend to avoid fields with rice vegetation.

The highest abundances of insectivore birds were associated with ecotones - such as the patches of "weeds" and puddles within the rice crop, field borders planted to Cajanus cajan, and adjacent hedges. The birds that visited both FV and MV plots are - frequently: black drongo (Dicrurus macrocercus), common myna (Acridotheres tristis), and paddyfield pipit (Anthus rufulus); seasonally: pond heron ( $A$. grayii), cattle egret (B. ibis), green bee-eater (Merops orientalis) and spotted dove (Streptopelia chinensis); and rarely: open-billed stork (Anastomus oscitans). The mean species diversity of birds per plot $\left(S_{\mathrm{b}}\right)$ over the period of 3 years (9 seasons) was significantly less in MV plots $\left(S_{\mathrm{b}}=\right.$ 4.3) than FV plots $\left(S_{\mathrm{b}}=9\right)$. The less diversity of birds in the chemicalized MV farm plots seems to be a result of pesticide use, which plausibly reduced the prey base for the insectivores. While a conclusive support to this conjecture is beyond the scope of this study, the highly significant difference $\left(t_{(\mathrm{df}=16)}=8.72, p<0.005\right)$ between FV and MV plots in mean bird diversity indicate a difference in prey availability for the birds between the two systems.

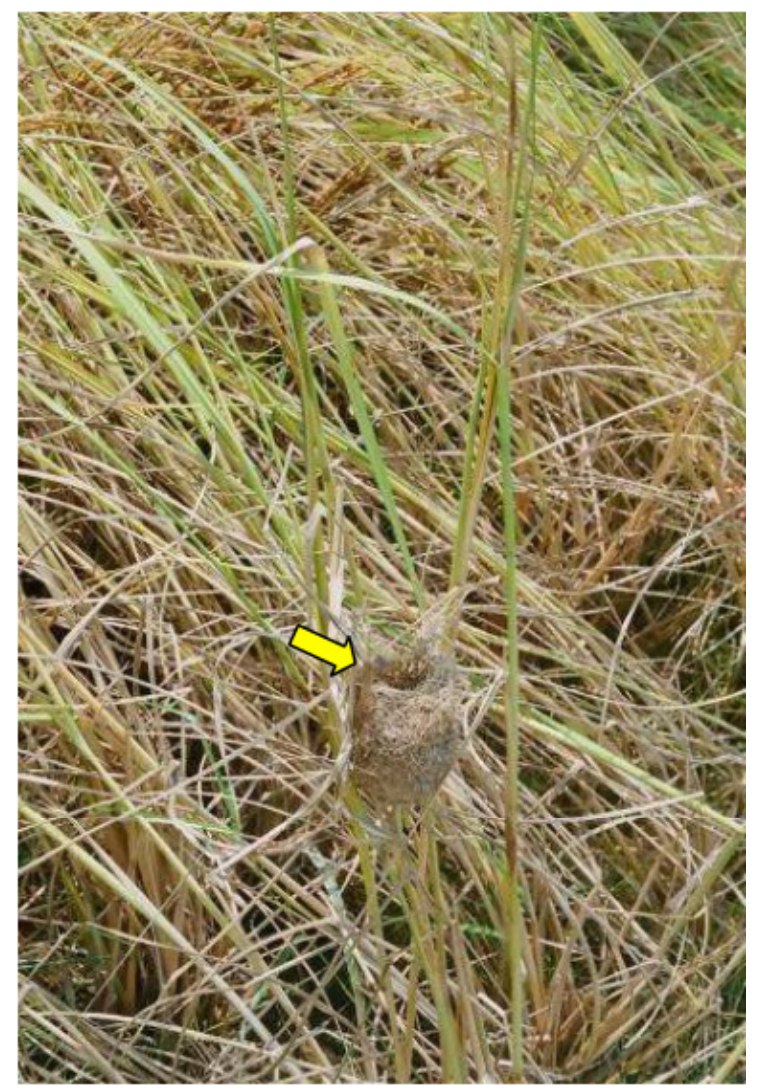

Plate 1. Tailor Bird Nest on A Hill of A Folk Rice Variety. (Arrow Points to the Nest Entrance).

The herb Ludwigia parviflora (Onagraceae) in the rice field was found to be effectively controlled in the period from September to late November, by the folivore beetle Haltica cyanea, which thereafter disappears from the rice field, only to reappear in the next summer. The L. parviflora is included in the rice food web through links to high trophic levels: its flowers are visited by several lepidopteran adults, like the Grass Jewel (Freyeria trochylus) and Grass Blue (Zizeeria karsandra), which in turn are preyed upon by Indian myna and the black drongo; these birds also prey on rice pests like the stem borer and leaf folder moths.

The seasonal rice ecosystems also include the blister beetle Mylabris pustulata, feeding on flowers of Cajanus cajan, planted on FV rice farm margins. The insect was also found to prey on flowers of several other plants (e.g., Ipomea fistulosa and Calliandra haematocephala) in the vicinity of the rice farm. Thus, the beetle is a component of the rice food web by way of sharing common predators with dragonflies, coccinelid beetles, and Leptocoryza acuta.

\subsection{Food web Properties}

Homogeneity $X^{2}$ test of the values of $S, L$ and species fractions shows that the FV $(N=42)$ and $\mathrm{MV}(N=6)$ food webs cannot be separated in different distributions of data 
points $(p>0.05)$, albeit with different means of species count $(S)$ and other properties. Separate examination of FV webs does not yield any significant change in the pattern of relationships between any pair of properties. Furthermore, when normalized structural properties are plotted against one another (such as pests per species, PTF against basal species fraction, BF), 4 among the 5 data points of the MV webs become coincident on those of FV webs. Therefore, all the FV and MV webs are analysed together for examining the relationships between different structural properties. The statistical strength of relationships between different structural properties of the real webs (FV and MV webs) and the computerized analog webs are summarized in Table 4. The salient results for the real and analog webs are discussed under separate rubrics below.

Table 4. Relationships between Food Web Properties

\begin{tabular}{|c|c|c|c|}
\hline Variables & $R^{2}$ & Slope & $p$ \\
\hline \multicolumn{4}{|c|}{ FV and MV Webs Combined } \\
\hline$S-L$ & 0.84 & 4.52 & $<0.00001$ \\
\hline$S-L / S$ & 0.41 & 0.06 & $<0.00001$ \\
\hline$S-\mathrm{BF}$ & 0.05 & -0.12 & NS \\
\hline$S$ - TBIB & 0.45 & 0.45 & $<0.00001$ \\
\hline$S-\mathrm{PT}$ & 0.17 & 0.19 & $<0.005$ \\
\hline$S$ - PTF & 0.04 & -0.29 & NS \\
\hline$S$ - PRF & 0.11 & 0.38 & $<0.05$ \\
\hline$S-\mathrm{PR} / \mathrm{PT}$ & 0.07 & 0.02 & $<0.08$ \\
\hline$S-\mathrm{WH}$ & 0.30 & 0.15 & $<0.0001$ \\
\hline$S-\mathrm{OM}$ & 0.31 & 0.32 & $<0.0001$ \\
\hline$S-$ OF & 0.13 & 0.07 & $<0.05$ \\
\hline$S-$ OLN & 0.13 & 0.07 & $<0.05$ \\
\hline BAS - TBIB & 0.27 & 1.52 & $<0.001$ \\
\hline BF - TBIB & 0.00 & -0.05 & NS \\
\hline BF - PTF & 0.25 & -1.25 & $<0.001$ \\
\hline $\mathrm{OM}-\mathrm{WH}$ & 0.15 & 0.81 & $<0.01$ \\
\hline PT - TBIB & 0.38 & 0.79 & $<0.00001$ \\
\hline PT - PR & 0.08 & 0.39 & $<0.05$ \\
\hline PTF - TBIB & 0.03 & -0.07 & NS \\
\hline \multicolumn{4}{|c|}{ Analog webs } \\
\hline$S-L$ & 0.86 & 8.44 & $<0.00001$ \\
\hline$S-L / S$ & 0.76 & 0.11 & $<0.00001$ \\
\hline$S-\mathrm{BF}$ & 0.33 & -0.25 & $<0.00001$ \\
\hline$S$ - TBIB & 0.47 & 0.57 & $<0.00001$ \\
\hline$S-\mathrm{PT}$ & 0.48 & 0.4 & $<0.00001$ \\
\hline$S$ - PTF & 0.02 & 0.13 & $<0.00001$ \\
\hline
\end{tabular}

(Table 4) Contd.....

\begin{tabular}{|c|c|c|c|}
\hline Variables & $\boldsymbol{R}^{2}$ & Slope & $\boldsymbol{p}$ \\
\hline \hline \multicolumn{4}{|c|}{ Analog Webs } \\
\hline$S$ - PRF & 0.46 & 0.67 & $<0.00001$ \\
\hline$S$ - PR/PT & 0.11 & 0.01 & $<0.00001$ \\
\hline$S$ - WH & 0.62 & 0.12 & $<0.00001$ \\
\hline$S$ - OM & 0.68 & 0.53 & $<0.00001$ \\
\hline$S$ - OF & 0.32 & 0.56 & $<0.00001$ \\
\hline$S$ - OLN & 0.37 & 0.07 & $<0.00001$ \\
\hline BAS - TBIB & 0.07 & 1.34 & $<0.00001$ \\
\hline BF - TBIB & 0.14 & 0.73 & $<0.00001$ \\
\hline BF - PTF & 0.03 & -0.36 & $<0.00001$ \\
\hline OM - WH & 0.41 & 2.93 & $<0.00001$ \\
\hline PT - TBIB & 0.66 & 1.18 & $<0.00001$ \\
\hline PT - PR & 0.48 & 0.4 & $<0.00001$ \\
\hline PTF - TBIB & 0.27 & 0.48 & $<0.00001$ \\
\hline
\end{tabular}

\subsubsection{FV and MVWebs}

The mean number of ontospecies of the FV webs is 33.7 , whereas that of the MV webs is 25.6. The difference between these means is highly significant (one-tailed $t_{(42,5)}=$ $6.01, p<0.005)$. When both FV and MV webs are pooled, the number of food links $L$ shows strong scale dependence, and the relationship is best described by the constant connectance hypothesis (Martinez 1992):

$$
\mathrm{L}=\mathrm{a} \mathrm{S} \mathrm{k}^{\mathrm{k}}
$$

where the constant $a=0.05$ and $k=2.11$ (Fig. 1). The value of $k$ does not significantly change when the smaller MV webs are eliminated from analysis. The linkage density $(L / S)$ is strongly scale dependent (Table 4), and the slope is not altered by eliminating the MV webs.

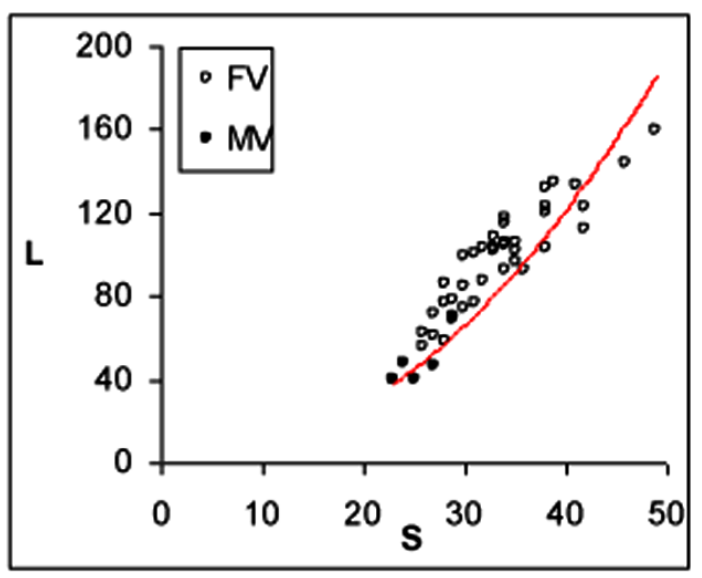

Fig. (1). The relationship of $L$ with $S$. The line shows the power relationship $L=0.05 S^{2.11}$ for all rice ecosystems combined.

Species fractions (TF, IF, and BF) show apparent scale dependence, but also high variances. As the number of basal components remains limited in the pooled rice ecosystems, 
BF (the number of basal species per species) decreases with $S$ (Fig. 2).

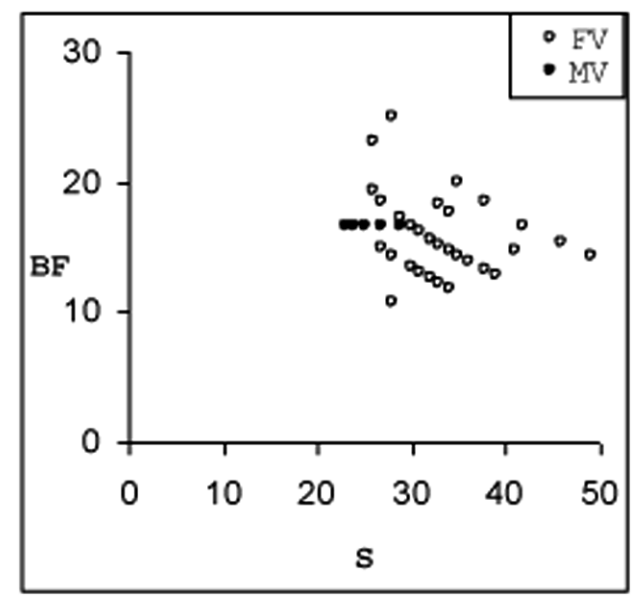

Fig. (2). The decline of BF with $S$.

The number of pests (PT), defined as ontospecies trophically connected with rice grain, rice plant sap and rice leaf tissue, increases linearly with $S$. However, the relationship of the pest fraction $(\mathrm{PTF}=\mathrm{PT} / S)$ with $S$ is not statistically significant (Table 4), although PTF is strongly related to the fraction of basal species $(\mathrm{BF}$, which includes parts of the rice plant).

At any given time-slice of observation, a particular rice pest may either occupy the top trophic level (in the absence of their predators) or intermediate level (preyed upon by species at higher trophic levels). Thus, rice pests are linked to the basal species through the sum of $\mathrm{TB}$ and IB links (shorthanded here as TBIB), which is likely to increase with $S$ as well as the number of pests (PT). This holds good for the rice food webs, showing a strong scale dependence of TBIB (Fig. 3). The direct relationship of TBIB with PT also holds strongly for all the real webs (Table 4). Likewise, the presence of each basal species entails at least a corresponding link to a consumer, and therefore there is a direct relationship of TBIB with the number of basal ontospecies (BAS). However, the relationships of pest linkages (TBIB) with the basal species per species (BF) and pest per species (PTF) are weak $(P>0.1)$.

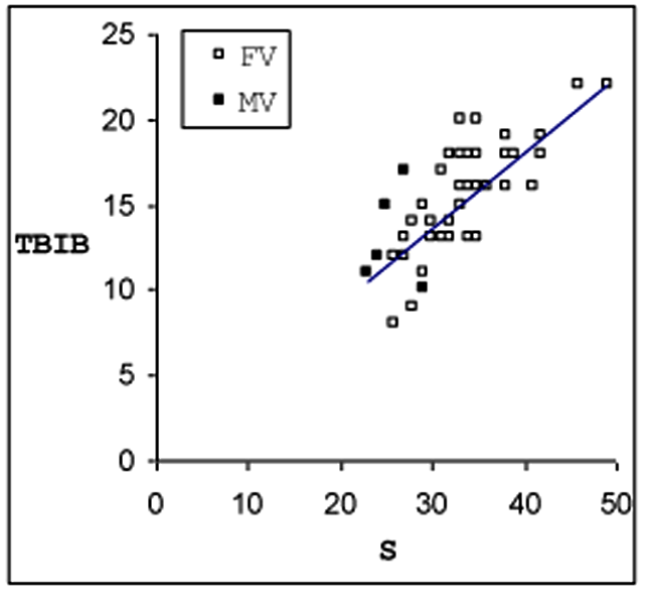

Fig. (3). Scale dependence of the sum of TB and IB links. The straight line depicts $b=0.447$.
The direct relationship of the sum of TB and IB links with the number of basal components (BAS), and an inverse, albeit weak, relationship of the same links with BF may be inferred from the dependence of the pest linkages on the scale-dependent BF: With a limited number of basal components of the rice farm ecosystem, BF tends to become smaller as $S$ increases (Fig. 2). Thus, the number of links to basal components (TBIB) will tend to be more numerous as the absolute number of basal components (BAS) increases, and $\mathrm{BF}$ correspondingly decreases. In other words, as BF decreases with increasing $S$, pest links to BAS increases.

The fraction of natural enemies or predators (PRF) of the rice pests appears to increase with $\mathrm{S}$. This implies that with increasing $\mathrm{S}$, the pest diversity declines, albeit slightly, whereas the diversity of natural enemies of pests increases in the rice ecosystem. The ratio of pests to predators (PT/PR) decreases with $\mathrm{S}$, indicating a proportionate increase in predator diversity in large speciose food webs. The slope of PT/PR and that of PRF against $S$ are both highly significant $(t=2.27, P<0.03)$. Conversely, the predator to pest (PR/PT) ratio of all rice webs combined appears to be weakly scale dependent $(P<0.08)$. The mean PR/PT for FV webs is 1.53 , which is significantly different from the mean of 1.18 predators per pest for MV webs. For all rice webs combined, the mean PR/PT equals 1.49.

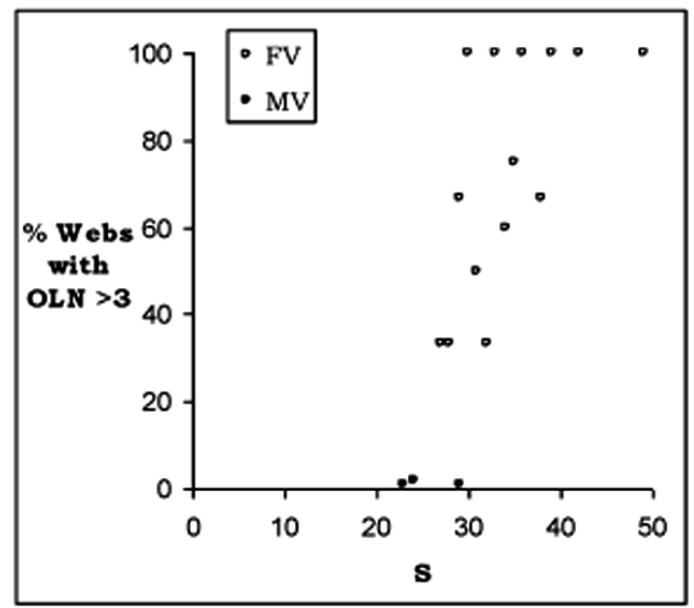

Fig. (4). Scale dependence of the frequency of food webs with OLN $>3$. The line shows regression with slope $=4.23$.

Most of the FV webs are more speciose and have significantly longer Web heights than MV webs. The mean web height (WH) of FV webs is 7.4 , compared to 5.4 in the case of MV webs. None of the MV webs had $\mathrm{WH}>6$, while the maximum WH for the FVs is 10 . The difference between the mean WH of FV and MV webs is highly significant ( $t=$ $2.64, p<0.01$ ). As Table 4 shows, when all types of systems taken together, WH tends to increase with $S(P<0.0001)$.

The number of omnivores (OM) strongly varies with $S$ (Table 4); the power function model explains the scale dependence of OM slightly better $\left(R^{2}=0.318\right)$ than the linear regression model $\left(R^{2}=0.314\right)$. Moreover, the number of trophic omnivores are strongly related with $\mathrm{WH}$, indicating that system complexity is strongly influenced by omnivory. The smaller MV webs have significantly lower mean number of omnivores $(\mathrm{OM}=3.4)$ than the larger $\mathrm{FV}$ webs $(\mathrm{OM}=8.7)$. 
The frequency of webs with predators occupying multiple levels of omnivory increases with $S$. The combination of co-occurring omnivory levels within a web seems to be random. For example, a web of $S=30$ may have predators occupying OL 1 and OL $8(\mathrm{OLN}=2)$, while other webs of the same size may contain omnivores occupying OL 1 alone $(\mathrm{OLN}=1)$, and so on. All rice webs feature multiple $\mathrm{OL}$, so that $2<\mathrm{OLN}<7$ for FV webs, and $2<\mathrm{OLN}<5$ for MV webs. Only one FV web with $S=29$ is recorded to have OLN $=6$ omnivores. While webs with $S>30$ tend to have a greater frequency of OLN $>3$ (Fig. 4), the pattern of increase in OLN does not appear to be definitive, presumably due to small sample size.

\subsubsection{The Analog Webs}

In the process of creating randomized species assemblages, a few ontospecies were selected that had no prey and no predator. The frequency of such "dangling species" $\left(P_{\text {dng }}\right)$ is negligible in realistic species assemblages $(<0.05$ in all webs), and monotonically decreases in larger systems (in webs with $\mathrm{S}>30, P_{\mathrm{dng}}<0.0005$ ).

The analog webs show a stronger power function relationship between $L$ and $S$ than do the real webs (Fig. 5). Correspondingly, the regression slope of link density $L / S$ against $S$ is steeper $(b=0.107)$ for the analog webs than for the empirical webs.

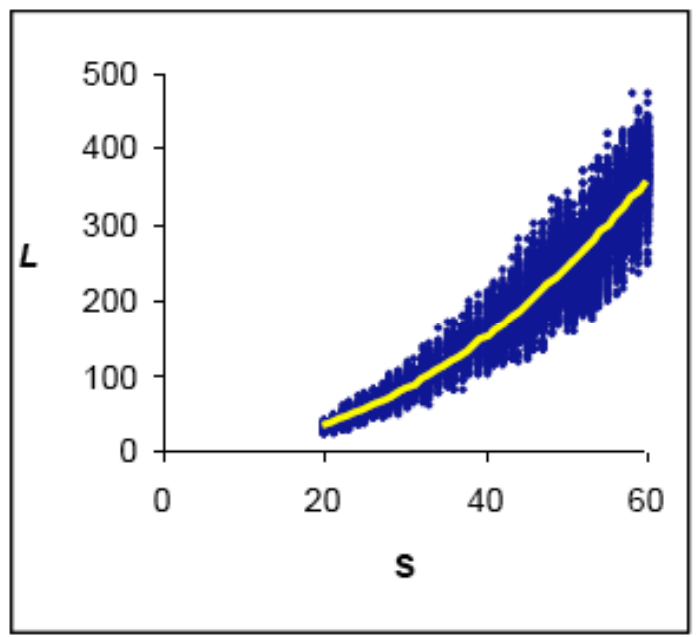

Fig. (5). The Power Function Relationship of $L$ with $S$ for Analog Webs. The line shows $L=0.055 \mathrm{~S}^{2.156}$

The fraction of rice pest organisms (PTF) decreases with $S$. However, PTF has a strongly inverse relationship $(P<$ $0.01)$ with the basal species fraction $(B F$, which includes parts of the rice plant). On the other hand, the number of predator ontospecies (PR) is related to the pest numbers (PT) with a strong $\left(R^{2}=0.64\right)$ power relationship $(\mathrm{PR}=2.27$ $\left.\mathrm{PT}^{0.86}\right)$, implying that for each pest ontospecies there are more than one natural enemy to control it. The mean number of predators per pest is 1.62 for all analog webs. The PR/PT ratio increases with system size, with a power function model $\left(\mathrm{PR} / \mathrm{PT}=0.34 S^{0.39}\right)$ explaining the data better $\left(R^{2}=\right.$ $0.163)$ than linear regression model $\left(R^{2}=0.107\right)$.

The relationship of all primary consumer (TBIB) links with PTF in the analog webs is strongly positive. The presence of each basal species entails at least one corresponding link to a consumer, and therefore the slope of
TBIB against the basal ontospecies number (BAS) is strongly positive $(P<0.005)$. However, both these relationships become negative $(P<0.1)$ when plotted against the basal species (BF) and pest species (PTF) as fractions of $S$. The TBIB links hold an inverse power relationship with BF (Fig. 6).

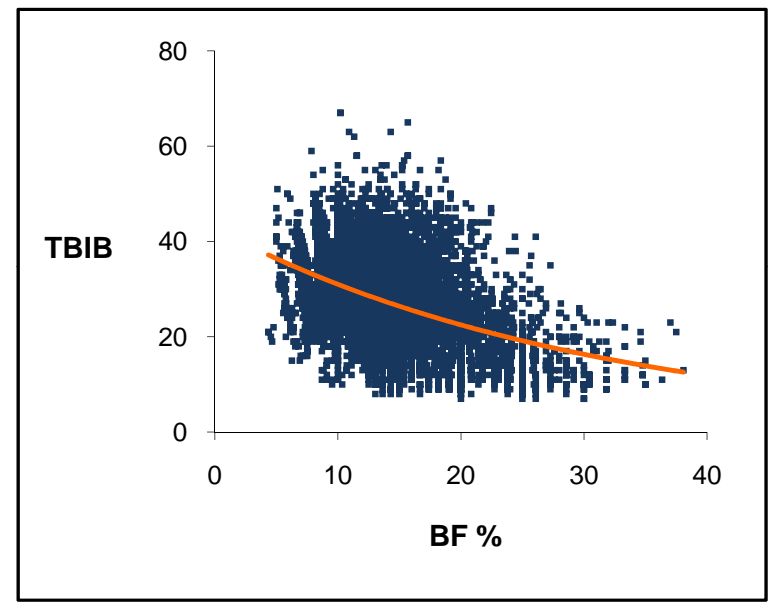

Fig. (6). The Relationship of All Primary Consumer (TB + IB) Links with the Basal Species Fraction. The line shows TBIB = $81.076 \mathrm{BF}^{-0.42}$.

The mean $\mathrm{WH}$ of the 16,400 random webs is 7.93 , with the specified upper limit of 10, a limit set by the observed longest chain length of empirical webs. The relationship of $\mathrm{WH}$ and $S$ is better described using a power function model $\left(R^{2}=0.67\right)$ than by a linear regression model $\left(R^{2}=0.62\right)$. Although larger webs may contain short chains, the frequency of webs with greater WH tends to increase with the system size. While small proportions of the webs with $\mathrm{S}$ $>20$ may have $\mathrm{WH}>5$, all webs with $\mathrm{S}>35$ have $\mathrm{WH}>4$, and all webs with $\mathrm{S}>50$ have $\mathrm{WH}>6$ (Fig. 7).

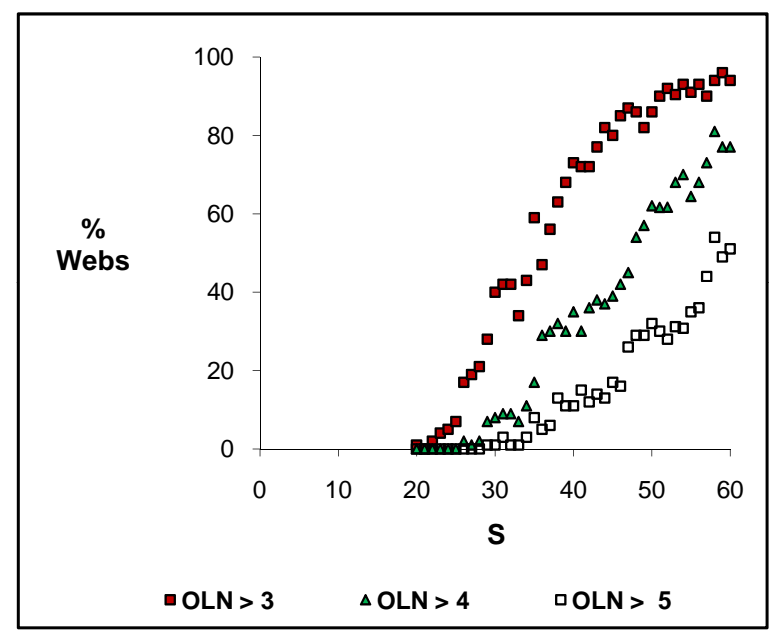

Fig. (7). Frequency of Webs with Web Heights Taller than 4, 6, and 8 as a Function of System Size.

Trophic omnivory tends to increase with $S$, and the relationship is extremely strong $(P<0.00001)$. The number of omnivory levels (OLN) also increases with $S$ (Table 4), although some larger $S$ may contain smaller OLN. 
Regardless of the combinations of omnivory levels in webs, all the webs with $S>35$ have OLN $>2$, and the frequency of webs with multiple omnivory levels increases with $S$ (Fig. 8). Over $90 \%$ of the webs with $S>50$ contains more than 3 levels of omnivory.

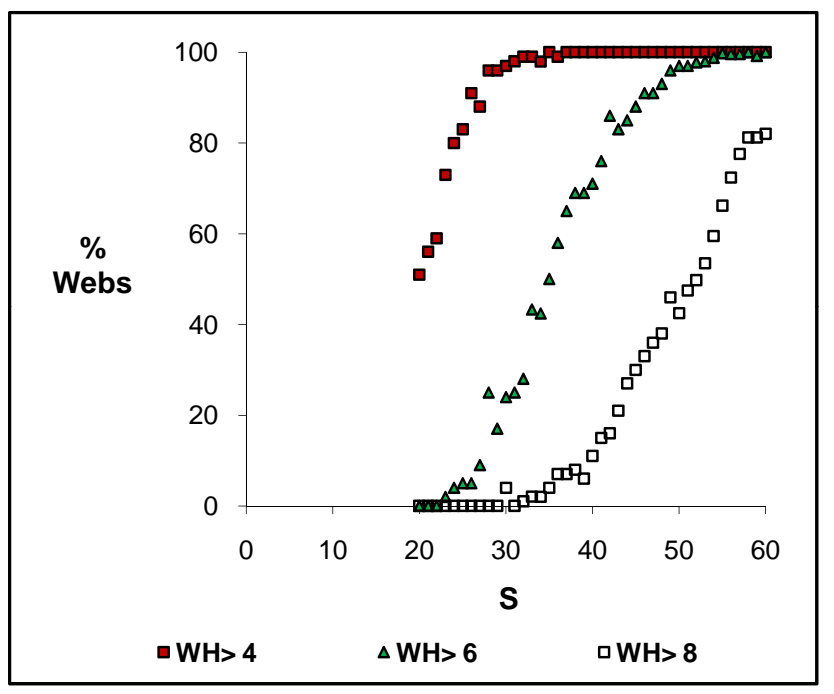

Fig. (8). The Frequency of Food Webs Incorporating Higher Levels of Omnivory.

With increasing species diversity in the ecosystem, both the food web height and degree of omnivory increases. When a fraction of predators are trophic omnivores, inclusion of their primary diets from lower trophic levels to higher trophic levels will increase their trophic position, leading to an increase in food-chain length (Takimoto et al. 2008). The chain lengthening effect of omnivore richness is evident in Fig. (9).

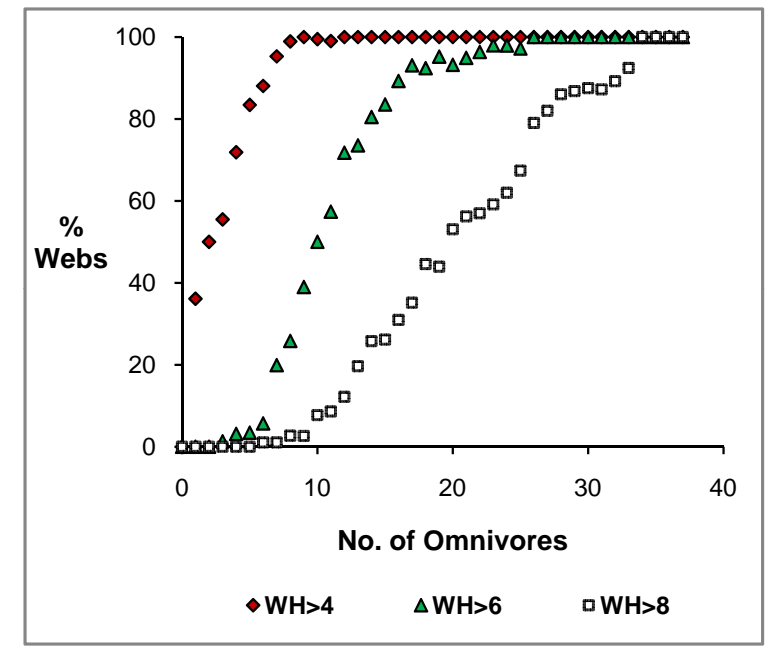

Fig. (9). The Relationship between Omnivory and the Frequency of Longer Food Chains.

\section{DISCUSSION}

Describing the relevant life history stages of organisms with different food habits as distinct ontospecies solves the problem of linear depiction of predation cycles, life history omnivory and intraguild predation (Deb 1995). While ontospecific division of trophospecies improves resolution of description, aggregation seems unavoidable for certain ontospecies (see Methods) which seem to share identical sets of prey and predators - species whose trophic relationship has not been distinguished at sufficiently high resolution. However, for large $(S>12)$ webs, such aggregation does not seem to affect general web properties (Bersier and Sugihara 1997).

Scale dependence of most food web properties, especially $L$ and $L / S$, are common in food webs that are dominated by generalist predation (Polis 1991; Deb 1995; Reagan et al. 1996). The rice food webs follow the same pattern, as most of the predators in the rice farm ecosystem are generalists. For instance, predatory insects and arachnids tend to consume all insect prey, whichever they manage to capture. Lycaenid larvae feed on diverse unrelated foods such as plants, fungi, lichens, cycads, ferns, conifers, mealybugs, scale insects, aphids, and larvae of ants (Venkatesha 2005). Frogs and lizards prey on a large range of invertebrate taxa, ranging from annelids to insects, diplopods and arachnids (Daniel 1983; Deuti and Bharati Goswami 1995; Whitaker and Captain 2004), depending on the prey body size. Stewart and Woolbright (1996) even reported lizard hatchlings and shelled snails from the stomach of the euryphagous frog Eleutherodactylus coqui. Higher level predators in the empirical rice communities described here - snakes, bandicoots, and mongoose - are all size-selective predators, preying on a large range of vertebrates and invertebrates. The fox (Vulpes bengalensis) is a scavenger as well as facultative predator, preying on dung beetles, mollusks (pers. observation), lizards, birds and rodents (Prater 1988). The diet spectrum of large aquatic birds like the large egret, open-billed stork and pond heron includes annelids, crustaceans, arthropods, mollusks, fish, frogs and reptiles of all manageable body size classes (Grimmet et al. 1998; BESG 2009). The widespread occurrence of generalist feeders renders all linkages and link proportions strongly scale-dependent.

The large number of analog webs adds to the statistical strength and robustness of conclusions. Expanding the sample size with computerized analog webs based on following real-life, non-random rules of species associations serves to etch out food web architectural patterns that may seem unclear from the small samples of empirical webs. The relationship between TBIB links and PTF is a case in point: TBIB appears to be directly related with PTF (Table 4), but the relationship is weak $(p>0.1)$ in the empirical webs. The computerized analog systems confirm the relationship to be definitively direct, at $0.01 \%$ level of significance (Table 4).

The salient patterns that emerge from the analyses of the food webs may be summarized as follows.

\subsection{Scale Dependence of Trophic Links}

The power-relationship between $S$ and $L$, first suggested by Cohen et al. (1990), has been empirically corroborated by later food webs studies (Martinez 1992; Deb 1995; Reagan et al. 1996). The scale dependence of trophic links $(L)$ is governed by the power function relationship:

$L=a S^{\mathrm{k}}$ 
In conformity with high-resolution food webs, $k$ in this study lies between 1.09 and 2.19. This study also confirms the scale dependence of all links and link fractions, as reported in previous studies of aquatic (Martinez 1992, 1993; Deb 1995), desert (Polis 1991) and forest communities (Reagan et al. 1996).

\subsection{Scale Dependence of Predator Richness and Density}

For each prey ontospecies, there are always more than one predator species (mean $\mathrm{PR} / \mathrm{PT}>1$ ) in all rice food webs. The mean predator density, $\mathrm{PR} / \mathrm{PT}=1.53$ for $\mathrm{FV}$ webs and 1.66 for the analog webs. However, the ratio for MV webs is considerably less $(\mathrm{PR} / \mathrm{PT}=1.18)$, presumably because the predatory insect diversity in the chemicalised MV farm plots was considerably less $($ mean $=9)$ than in FV plots $($ mean $=$ 12.1), and the difference between means is highly significant (two-tailed $\left.t\right|_{(41,5)}=2.47, p<0.05$ ).

The FV food webs contain a large diversity of predators. Spiders, ants, odonates, coccinelid beetles, and vertebrates (frogs, reptiles and carnivorous birds) comprise the major predator guilds. In addition, potter wasps, fireflies, Grylotalpa sp., lycaenid larvae, mantids, mongoose (Herpestes edwardsi), and fox (Vulpes bengalensis) are present in some of the time slices of rice ecosystems. In each empirical food web, the predator ontospecies richness outnumbers the pest species richness. This is not surprising, because on the FV farms with no pesticide application, the herbivore fraction of arthropods remains at less than onefifth of the fraction of predators. A majority of arthropods on rice farms in Asian rice growing countries are natural enemies of rice pests (Schoenly et al. 1998; Paoletti et al. 1999). Heong and Schoenly (1998) showed that insecticide application reduced the total population of herbivores by $1 \%$ while that of predators and parasitoids was reduced by 42 and $37 \%$ respectively. Plant hoppers increased by $23 \%$ while spiders decreased by $61 \%$ indicating that insecticide spray favours plant hopper development. A more recent study shows that on rice farms with no pesticide application, $11.2 \%$ of arthropods was herbivores, while predators were 58\% (Heong et al. 2007).

Predation by spiders constitutes a highly effective control of crop pest populations. In a field study by Sathiamma (1995), the total density of seven prominent spider species corresponded closely over time to the density of mites, and the control was sufficient to obviate the need for chemical applications. Spider's presence itself can reduce insect herbivory by eliciting defensive behavior in the prey (e.g., the cessation of the prey's feeding or reduced breeding) as well as by direct predation on the pests (Riechert 1999).

Bird predation on insects tends to reduce plant damage by arthropod pests in agroecosystems (Philpott et al. 2004; Van Bael et al. 2008). As described in section 2.1, the mean diversity of birds visiting the FV farms was significantly higher $($ mean $=9)$ than those visiting the MV farms (mean = 4.3) located close to the FV farms. The lesser bird diversity in the MV farm plots may be linked to the considerably lesser availability of their insect prey on MV plots than on FV plots, as indicated by the relatively lower mean predatory insect diversity in MV webs (see above).
It seems likely that pesticide-induced depletion of insect predators in MV farm plots led to the suppression of predator richness and $\mathrm{PR} / \mathrm{PT}$ ratio. This conjecture seems to be corroborated by recent studies, which affirm that pesticides reduce the number of predator species on the rice pests, and favours subsequent buildup of pests (Heong et al. 2007), thereby suppressing the PR/PT ratio. Furthermore, application of nitrogen fertilizers to modern agroecosystems favours pest population buildup, which is enhanced by the chemical elimination of predators (Settle et al. 1996; Chen 2008).

The FV systems have significantly higher predator richness than MV systems, but whether high predator diversity would dampen or enhance pest control is a contested issue (Bruno and Cardinale 2008). While some studies (e.g. Finke and Denno 2005; Schmitz 2007) report that a high diversity of predators (incorporating intra-guild predation) tend to reduce their pest control function, others (Wilby et al. 2005; Byrnes et al. 2006) report that predator richness strengthens trophic cascades. Intra-guild predation may dampen trophic cascades in small food webs (Denno et al. 2004), but the presence of omnivores may alter this effect by ontogenetic prey switching (from one trophic level to another) in large ecosystems (Deb 1995; Polis and Strong 1996). Experimental addition of omnivores can increase the producer biomass through trophic cascades by reducing intermediate predation pressure (Katano et al. 2006). In large systems like the rice food webs under consideration, increase in predator richness contributes to enrichment of omnivory (see next section 4.3), which is likely to reduce intra-guild predation.

The cascading effect is also influenced by the behavior of predators. Simulation studies of ecosystems with different types of predators show that (a) actively foraging predators may be effective regulators of sedentary herbivore populations; and that (b) widely foraging omnivores, unlike sit-andwait omnivores, are unlikely to disrupt herbivore population suppression caused by intermediate predators, and may instead enhance herbivore suppression (Rosenheim and Corbett 2003). This finding is relevant in the context of this study, because actively foraging predators, like spiders, odonates, ants, coccinelid beetles, predatory birds, lizards and frogs are naturally abundant on tropical rice farms, unless eliminated by pesticide use.

\subsection{Scale Dependence of Omnivory}

Contrary to predictions in food web theory (Pimm 2002), trophic omnivory is common in real-life communities (Deb 1995; Polis and Strong 1996; Reagan et al. 1996). Both OM and the OLN increase with $S$ (Figs. 7 and 8), implying that the assumption of the paucity of omnivory in natural ecosystems is unrealistic. While the possible number of omnivory levels examined here is not comprehensive, Fig. (8) suffices to depict the increasing likelihood of encountering higher omnivory levels with increasing $S$.

In spite of dynamic constraints on omnivory (Pimm 2002), why is omnivory common in natural and near-natural ecosystems, including agroecosystems that persist at least long enough for observation? Likely explanations (mutually supportive) include: (a) tropho-dynamic optimal foraging theory: predators might sometimes feed at lower trophic 
levels because of the greater biomass and energy available at these levels. Hence, same- or different-chain omnivory may result; (b) dynamic stability theory: omnivory may be a favored compromise because it effectively shortens food chains (by shortening energy flow routes to higher predators), thereby promoting their persistence; life-history omnivory also stabilizes the food web by the release in predation pressure at different life stages (see review by Coll and Guershon 2002). Explanation (a) supports the observation that in long-chained food webs, omnivores on high trophic levels derive much of their energetic needs from trophic levels near the bottom of the chain. In this study, omnivory links from owl, drongo and lizard always include the first intermediate (pest) level. Life history omnivores are also common in the rice food webs, releasing predation pressures in different seasons on different trophic levels, lending support to the explanation (b). Recent models incorporating realistic conditions of omnivory suggest that addition of omnivores may lead to more persistent webs (McCann and Hastings 1997, Borrvall et al. 2000).

\subsection{Scale Dependence of Web Height}

Food chain length or web height is the simplest measure of vertical diversity of a community. Because it strongly influences magnitude and efficiency of trophic transfer, web height (WH) is directly related to ecosystem functioning (Duffy et al. 2007). WH is a convenient parameter to measure food chain length variations, and reflects the effect of addition or removal of trophic levels from the food web. Consistent with current food-web theory (Post 2002; Dunne et al. 2002, 2004), WH varies strongly among the food webs, increasing with $S$. In this study, the upper limit of WH for all empirical rice food webs was 10 , and therefore the computerized analog webs in this study are constrained to have 2 $\leq \mathrm{WH} \leq 10$. Within this constraint, the mean values of $\mathrm{WH}$ (7.4 for $42 \mathrm{FV}$ webs, 7.9 for 16,400 analog webs) are comparable to the detailed terrestrial food webs described by Polis (1991: mean WH =6.7) and Reagan et al. (1996: WH $=8.2$ ). The significantly lower value of mean $\mathrm{WH}=5.4$ (and low species diversity) of the MV webs clearly show that the MV webs are drastically simplified ecosystems. The poor floral diversity (Appendix C) and low predator richness on MV farm plots is a result of the application of pesticides and herbicides (see Sec. 2.1). This finding agrees with previous empirical studies, showing that insecticide spray on rice farms caused significant reduction in food chain length, through predator emigration and direct killing action of insecticides (Heong and Schoenly 1998; Heong et al. 2007).

The analog webs are composed of more species $(20 \leq \mathrm{S} \leq$ 60) than the FV and MV systems contain, and demonstrate the scale-dependence of the frequency of tall webs. The large number of computerized analog webs shows that the web height, or the longest chain length, tends to increase with $S$ (Fig. 7). This is consistent with the current understanding of food chain length increasing with ecosystem size, incorporating more component species (Post 2002; Takimoto et al. 2008). As the ontospecies diversity increases, the species occupying successively higher trophic levels tend to increase, which allows lengthening of $\mathrm{WH}$.

Trophic omnivory can also have profound influence on food chain length. Growing empirical evidence suggests that trophic position is a continuous index averaging the number of trophic levels up the web height through all trophic pathways. When top predators are trophic omnivores, changing their primary diets from lower trophic levels to higher trophic levels will increase their trophic position, leading to an increase in food-chain length (Takimoto et al. 2008). This view is validated by the 16,400 analog webs examined here, showing a strong relationship of web height with the number of omnivorous predators (Fig. 9).

\section{CONCLUSION}

Computerized models of ecosystems can be useful to "the degree to which the virtual world reflects natural reality" (Paine 2004: 39). Earlier models of ecosystems, built on several unrealistic assumptions (e.g., random species associations), often yielded wrong predictions, such as short food chains, and rarity of omnivory (Cohen et al. 1990; Pimm 2002). These predictions have been challenged by empirical studies (Martinez 1993; Deb 1995; Reagan et al. 1996) as well as by more realistic models incorporating nonrandom species associations (Polis and Strong 1996; Dunne et al. 2002; Martinez et al. 2005; Bascompte and Melian 2005). This study, based on empirically observed ecosystems as well as their simulated analogs, confirms scale dependence of (a) link density, (b) basal species fraction, (c) predator density (PR/PT), (d) web height, (e) omnivory, and (f) levels of omnivory. Furthermore, this study links the rice food web architectural properties to selected agroecosystem functions, such as the diversity of predators and omnivores.

While predation on herbivores can effectively control pest populations on host plants, predation from higher trophic levels on the herbivores and intermediate predators may have varying effects on suppression of herbivore populations (Rosenheim and Corbett 2003). This study shows that the rice field houses an abundance of actively foraging omnivores - coccinelid beetles, ants, predatory wasps, odonates, fireflies, ranid frogs that climb the rice plant to eat insects, Calotes versicolor, insectivorous birds like myna, pond heron and bee eater. Unless eradicated by the use of pesticides (as in MV systems), the rich predator diversity is likely to override the pest species richness (as in FV systems) with a higher PR/PT ratio. Recent empirical studies indicate that actively foraging omnivores in complex ecosystems are likely to enhance herbivore suppression (Rosenheim and Corbett 2003). A comparison of crop yield loss (due to pest damage) in FV vs. MV systems (Deb, unpublished data) is beyond the scope of this paper. However, analyses of the food web architecture here do reveal (i) a significant increase in predator diversity with both $S$ and pest diversity (PT), (b) a direct relationship of the predator richness (PR) with the pest richness (PT) in both the real and model webs, and (c) a strong direct relationship between $S$ and the ratio of predator to pest diversity (PR/PT) (Table 4). These three relationships conjointly indicate that predator diversity tends to increase with both system size and pest diversity, and the ratio of predator- to pest richness declines progressively with on-farm biodiversity.

Scale dependence of PT/ PR ratio in this study is consistent with the notion that greater on-farm biodiversity can enhance (1) more natural enemies of insect pests, and (2) biotic compensation for the absence of synthetic pesticides 
(Letourneau and Bothwell 2008). Greater biodiversity may also contribute to the stability and resilience of the farm ecosystem against large perturbations from climatic vagaries or pest and pathogenic outbreaks (Kinzig et al. 2002; Tilamn et al. 2002). Recent empirical and theoretical studies (Dunne et al. 2002, 2004; Worm and Duffy 2003; Tilman et al. 2006) suggest that enrichment of biodiversity and complexity improves temporal stability and resilience, and that the loss of highly connected ontospecies will tend to induce higher levels of secondary extinctions than loss of random taxa. Furthermore, greater complexity of food webs may "intrinsically lower the likelihood of chaotic community dynamics" (Fussmann and Heber 2002).

Biodiversity is depleted in modern rice production systems through monocultures and the use of pesticides and herbicides, which simplify the on-farm ecosystem structure. Systemic pesticides are known to impact severely on populations of a large number of arthropod and vertebrate predators, leading to a collapse of vertical diversity of the rice food web (Heong and Schoenly 1998; Heong et al. 2007) This study indicates that more species-rich farm ecosystems, with longer food chains and more trophic omnivores, tend to have a greater diversity of predators than do species-poor, simplified agroecosystems. Less ontospecies diversity in MV systems is associated with truncation of web complexity (e.g. shorter WH), which may have adverse impacts on ecosystem productivity (Memmott et al. 2005; Duffy et al. 2007), via loss of supporting ecosystem services (e.g., generation of soil fertility, pest control, pollination) (Tilman et al. 2002; Hooper et al. 2005; Tscharntke et al. 2005; Heong et al. 2007). In light of this understanding, it is imperative to put a strong policy emphasis on enhancing biodiversity and ecological complexity in agroecosystems.

\section{ABBREVIATIONS}

$\mathrm{BAS}=$ Basal species

$\mathrm{BF} \quad=\quad$ Basal species fraction

$\mathrm{FV}=$ Folk rice variety

$\mathrm{GCA}=$ Gut content analysis

IB $=$ No. of links between intermediate and basal

levels

MV = Modern rice variety

$\mathrm{OL}=$ Omnivory level

OLN = Number of omnivory levels

$\mathrm{OM}=$ Number of trophic omnivores

Pdng $=$ Fraction of dangling species

$\mathrm{PRF}=$ Fraction of predators on rice pests

PTF $=$ Fraction of pest organisms

$\mathrm{TB}=$ No. of links between top and basal levels

TBIB $=$ Sum of TB and IB links

\section{ACKNOWLEDGEMENTS}

It is my pleasure to record my gratitude to the late Rabi Mahato, Debdulal Bhattacharya, Sanjay Sinha, Swapan Mishra and Arun Ram, whose meticulous collection of field data over years formed the basis of this work. I am thankful to Dr. Swapan Chatterjee and friends at Zoological Survey of India, and to S. Karmakar and Anupam Paul of the West Bengal Agriculture Department, for help in identifying selected plants and insects, and to Dr. Louis-Félix Bersier for constant encouragement and support to my work. I am grateful to two anonymous reviewers for their meticulous critique of an earlier draft of the mss.

\section{Appendix}

Appendix A. A List of Ontospecies Recorded from > 3 Sightings on Rice Farm Plots at Basudha Research Station (1999-2000, 200203)

\begin{tabular}{|c|c|c|c|}
\hline \multirow{2}{*}{ Basal } & \multicolumn{3}{|c|}{ Trophic Levels } \\
\hline & Intermediate- I (Herbivores) & Higher Intermediates & Top \\
\hline Phytoplankton & Annelida & Copepod & \\
\hline Soil \& Detritus & Earthworms (3 spp.) & Cyclopoid adults & \\
\hline \multirow[t]{2}{*}{ Pollen \& Nectar(of companion flora) } & Millipedes (2 spp.) & & Black drongo (Dicrurus macrocercus) \\
\hline & & Arachnida & Open-billed stork (Anastomus oscitans) \\
\hline Leaf tissue & Rotifera & Argiope sp. & Pond heron (Ardeola grayii) \\
\hline Plant sap & Copepod nauplii & Heteropoda ventria & Jungle owlet (Glaucidium radiatum) \\
\hline \multirow[t]{2}{*}{$\begin{array}{l}\text { Flowers (of Cajanus cajan and Ludwigia } \\
\text { spp.) }\end{array}$} & Cladocera & Hippasa holmarae & Barn owl (Tyto alba) \\
\hline & & Lycosa sp. & Grey nightjar (Caprimulgus indicus) \\
\hline \multirow[t]{2}{*}{ Graminid Seeds } & Crustacea & Menemenus bivittatus & Hoopoe (Upupa epops) \\
\hline & Crab & Oxyopus sp. & \\
\hline
\end{tabular}



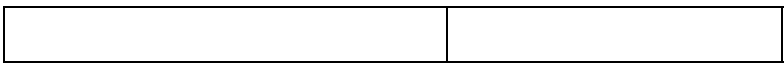

Smeringopus pallidus

(Appendix A.) Contd......

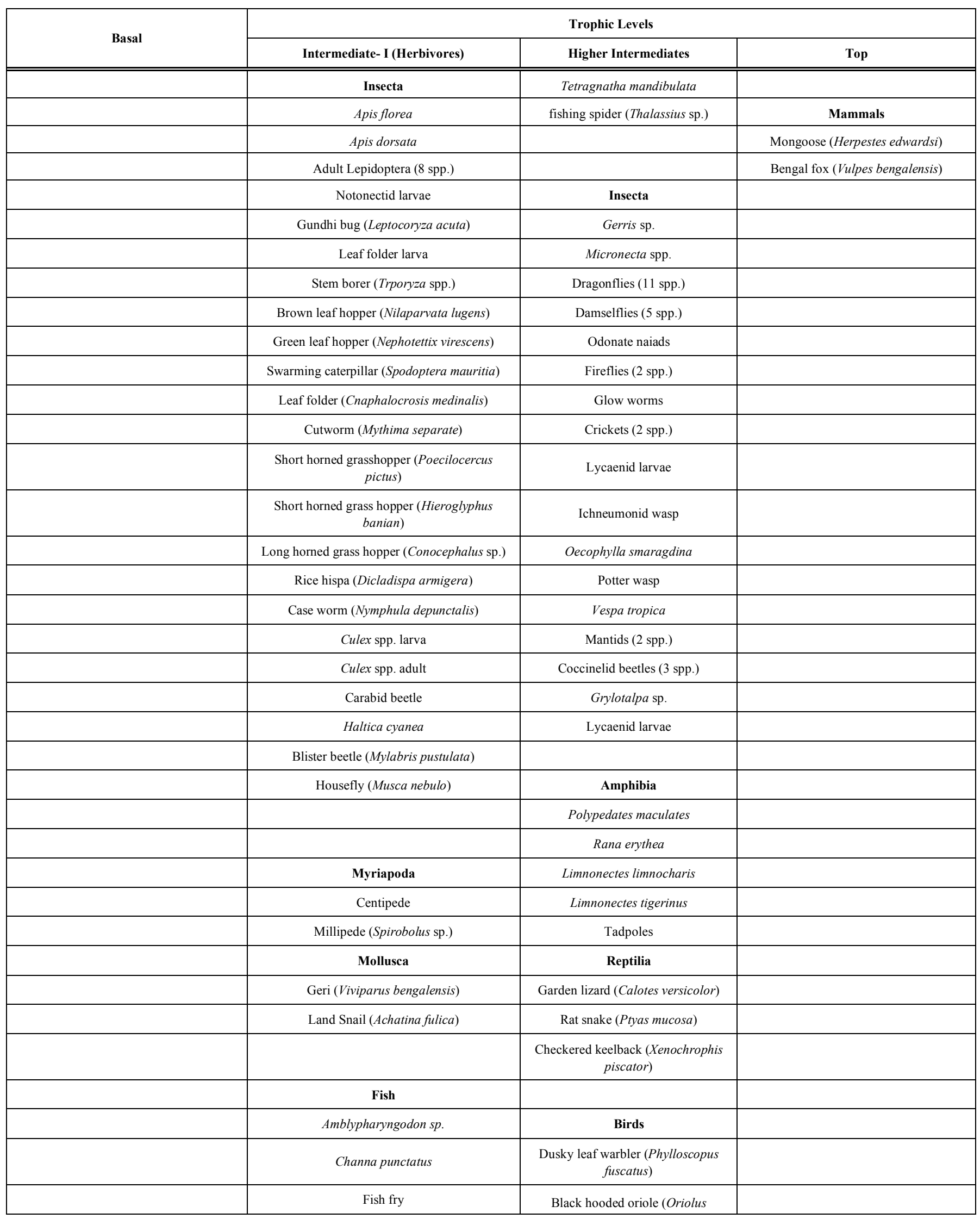




\begin{tabular}{|l|l|l|l|}
\hline & & xanthornus) & \\
\hline & & Green bee eater (Merops orientalis) & \\
\hline
\end{tabular}

(Appendix A.) Contd.......

\begin{tabular}{|l|c|c|c|}
\hline \multirow{2}{*}{ Basal } & \multicolumn{3}{|c|}{ Trophic Levels } \\
\cline { 2 - 4 } & Intermediate- I (Herbivores) & Higher Intermediates & \multicolumn{1}{|c|}{ Top } \\
\hline \hline & Birds & Paddyfield pipit (Anthus rufulus) & \\
\hline & Spotted dove (Streptopelia chinensis) & Tailor bird (Orthotomus sutorius) & \\
\hline & Red vented bulbul (Pycnonotus cafer) & Common myna (Acridotheres tristis) & \\
\hline & & Cattle egret (Bubulcus ibis) & \\
\hline & Mammals & Coucal (Centropus sinensis) & \\
\hline & Mus musculus & Manmals & \\
\hline & Rattus rattus & & \\
\hline
\end{tabular}

\section{Appendix B. Established Food Links between Pairs of Predators/Parasitoids and Prey/Host Ontospecies}

\begin{tabular}{|c|c|c|}
\hline Predator & Prey/Host & References \\
\hline Copepod zooplankton & Rotifera, Cladocera, phytoplankton & Deb (1995) and citations there \\
\hline Copepod nauplii & Phytoplankton & Deb (1995) and citations there \\
\hline Cladocera \& Rotifera & Phytoplankton, detritus & Deb (1995) and citations there \\
\hline Fish fry & Zooplankton & Deb (1995) and citations there \\
\hline Tadpoles & Zooplankton, insect larvae & Deb (1995) and citations there \\
\hline Odonate larvae & Zooplankton, fish fry, tadpoles & Deb (1995) and citations there \\
\hline $\begin{array}{c}\text { Leaf folder (Cnaphalocrocis medinalis), caseworm } \\
\text { (Nymphula depunctalis), rice hispa (Dicladispa armigera), } \\
\text { cutworm (Spodoptera } \mathrm{sp} .)\end{array}$ & Rice leaf tissue. & IRRI (2009) \\
\hline Crickets, Grasshoppers & $\begin{array}{c}\text { Rice leaf tissue, rice grains, stem borer eggs, eggs and nymphs } \\
\text { of leafhoppers and plant hoppers. }\end{array}$ & Chitra et al. (2000), Kraker et al. (2000) \\
\hline $\begin{array}{l}\text { Rice stem borer (Tryporyza sp.), Brown plant hopper } \\
\text { (Nilaparvata lugens), Green leafhopper (Nephotettix sp.) }\end{array}$ & Rice phloem (sap). & \\
\hline Gundhi bug (Leptocorisa acuta) & Rice grains. & IRRI (2009) \\
\hline Blister beetle (Mylabris pustulata) & Flowers of Cajanus cajan, Ipomea fistulosa & Mani (1995) \\
\hline Lycaenid caterpillar & Fungi, aphids, Leptocoryza acuta larvae & Venkatesha (2005), direct observation \\
\hline Haltica cyanea & Ludwigia parviflora & Direct observation \\
\hline Fireflies (Luciola gorhami \& L. vespertina) & Beetle larvae, plant hoppers & Direct observation \\
\hline Glow worms & Earthworm, millipede & Direct observation \\
\hline Weaver ant (Oecophylfsla smaragdina) & $\begin{array}{c}\text { Earthworm, fungi, dipteran eggs and larvae, eggs of leafhoppers } \\
\text { and grasshoppers, cutworm larva, eggs \& larvae of pyralids, } \\
\text { nectar, honeydew, detritus }\end{array}$ & Folk knowledge, direct observation, \\
\hline Snail (Bellamya bengalensis) & Phytoplankton, detritus & Folk knowledge, direct observation \\
\hline Crab & Snails, detritus & Folk knowledge; direct observation \\
\hline Earthworm & Detritus & Folk knowledge \\
\hline Millipede & Detritus, eggs of short-horned grasshoppersfs & $\begin{array}{l}\text { Folk knowledge; IRRI (2009); direct } \\
\text { observation }\end{array}$ \\
\hline Centipede & Earthworms, small snails, beetle larvae, detritus & BESG (2009), direct observation \\
\hline
\end{tabular}




\begin{tabular}{|c|c|l|}
\hline Fishing spider (Thalassius sp.) & $\begin{array}{c}\text { Gerris sp., Hydrometra sp., Micronecta sp., fish fry } \\
\text { (Amblypharyngodon sp.), Limnonectes tadpoles, green } \\
\text { leafhopper, cutworm larva, caseworm larva. }\end{array}$ & Sebastian and Peter (2009), direct observation \\
\hline Long jawed spider (Tetragnatha mandibulata) & $\begin{array}{c}\text { Butterflies, pyralid moths, lavae and eggs, damselflies, wasps, } \\
\text { housefly, eggs of deltocephalids and delphacids }\end{array}$ & Sebastian and Peter (2009), direct observation \\
\hline
\end{tabular}

(Appendix B) Contd......

\begin{tabular}{|c|c|c|}
\hline Predator & Prey/Host & References \\
\hline St. Andrew's cross spider (Argiope anasuja) & $\begin{array}{l}\text { Butterflies, pyralid moths, crickets, grasshoppers, bugs, } \\
\text { Grylotalpa sp., Haltica cyanea, wasps, housefly, damselflies, } \\
\text { dragonfly juveniles, Lycosa, Oxyopes and Smeringopus spiders }\end{array}$ & Sebastian and Peter (2009), direct observation \\
\hline Wolf spider (Lycosa sp.) & $\begin{array}{l}\text { Pyralid moths \& larvae, butterflies, crickets, deltocephalid and } \\
\text { delphacid hoppers, gundhi bug, cicads, tettigonids, Haltica } \\
\text { cyanea, damselflies, Oxyopes and Smeringopus spiders }\end{array}$ & Sebastian and Peter (2009), direct observation \\
\hline Sheet web spider (Hippasa holmarae) & Cicadellid leaf hoppers, housefly, Culex sp. & Sebastian and Peter (2009), direct observation \\
\hline Lynx spider (Oxyopes sp.) & $\begin{array}{l}\text { pyralid moths \& larvae, gall midge, gryllids, deltocephalid and } \\
\text { delphacid hoppers, housefly, damselflies, fireflies. }\end{array}$ & Sebastian and Peter (2009), direct observation \\
\hline Frogs & $\begin{array}{c}\text { Beetles, odonates, grasshoppers, crickets, moths and butterflies, } \\
\text { ants, centipedes, arachnids, earthworm }\end{array}$ & $\begin{array}{l}\text { Bharati Goswami and Deuti (1995), direct } \\
\text { observation }\end{array}$ \\
\hline Calotes vesicolor & $\begin{array}{l}\text { Beetles, odonates, grasshoppers, crickets, moths and butterflies, } \\
\text { ants, centipedes, arachnids, annelids, arachnids, centipedes }\end{array}$ & Whitaker (2006), direct observation \\
\hline Rat snake & Frogs, lizards, beetles, myriapods, arachnids, rodents & Whitaker (2006), direct observation \\
\hline Checkered keelback & Fish, crabs, aquatic insects, frogs, lizards, rodents & Whitaker (2006) \\
\hline Pond heron, egrets & $\begin{array}{c}\text { Beetles and beetle larvae, odonate larvae, gerrids, crabs, snails, } \\
\text { fish, frogs, lizards }\end{array}$ & Grimmet et al. (1998), direct observation \\
\hline Open-billed stork & crabs, snails, fish, frogs, lizards & Grimmet et al. (1998), direct observation \\
\hline Common myna & Beetles, odonates, grasshoppers, beetle larvae, bird nestlings & Moeed (1976), Sengupta (1968), BESG (2009) \\
\hline Black drongo & $\begin{array}{l}\text { Beetles, locusts, crickets, grasshoppers, moths and butterflies, } \\
\text { odonates, bees, ants, mantids, small lizards }\end{array}$ & BESG (2009), direct observation \\
\hline Green bee-eater & $\begin{array}{c}\text { Bees, wasps, moths, crickets, odonates, termites, moths and } \\
\text { butterflies }\end{array}$ & Fry and Fry (2008), BESG (2009) \\
\hline Tailor bird & $\begin{array}{l}\text { Houseflies and other flies, bees, spiders, termites, grasshoppers, } \\
\text { some bugs, moths }\end{array}$ & BESG (2009) \\
\hline Leaf warbler & Spiders, ants, & Grimmet et al. (1998) \\
\hline Spotted dove & Cereal seeds, fruits, spiders & Grimmet et al. (1998) \\
\hline Hoopoe & $\begin{array}{l}\text { Dung beetles, Mylabris, Haltica, beetle larvae, millipedes, } \\
\text { centipedes, frogs, lizard, small snakes }\end{array}$ & BESG (2009), direct observation \\
\hline Owls and nightjars & $\begin{array}{c}\text { Beetles, caterpillars, grasshoppers, termites, cicads, crickets, } \\
\text { spiders, centipedes, millipedes, snails, frogs, lizards, small } \\
\text { snakes, small birds and nestlings, rats. }\end{array}$ & $\begin{array}{l}\text { Burton (1984), Holyoak (2001), folk } \\
\text { knowledge, direct observation }\end{array}$ \\
\hline Mice & Cereal grains & Folk knowledge \\
\hline Bandicoot (Bandicota bengalensisi) & Snails, small crabs, cereal grains & Prater (1988), direct observation \\
\hline Mongoose (Herpestes edwardsi) & $\begin{array}{c}\text { Crickets, beetles,snails, small crabs, mice and rats, lizards, } \\
\text { snakes except Ptyas mucosus. }\end{array}$ & Prater (1988), folk knowledge \\
\hline Fox (Vulpes bengalensis) & $\begin{array}{l}\text { Snails, crabs, scarabid beetles, small birds, rodents, carcasses, } \\
\text { ripe fruits. }\end{array}$ & Folk knowledge, direct observation \\
\hline
\end{tabular}

\section{Appendix B.}

\section{Supplementary References}

Burton JA (Ed) (1984) Owls of the World: Their evolution, structure and ecology. Revised edition. Peter Lowe, London.

Chitra, N, Soundararajan, RP \& Gunathilagaraj, K (2000). Orthoptera in rice fields of Coimbatore. Zoos' Print Journal, $15,309-311$.

Fry, CH \& Fry, K (1992) Kingfishers, Bee-eaters and Rollers. Princeton University Press: Princeton, NJ.

Holyoak, DT (2001) Nightjars and Their Allies. Oxford University Press: Oxford. 
IRRI (2009) Online Knowledge Bank. International Rice Research Institute. Manila URL: <www.knowledgebank.irri.org>

Kraker, J, de, van Huis, A, van Lenteren, JC, Heong, KL \& Rabbinge, R (2000) Identity and relative importance of egg predators of rice leaffolders (Lepidoptera: Pyralidae). Biological Control, 19, 215-222.

Mani MS (1995) Insects. 2nd ed. National Book Trust: New Delhi.

Moeed, A (1976) Foods of the Common Myna (Acridotheres tristis) in central India and in Hawke's Bay, New Zealand. Notornis, 23, 246249.

Sengupta, S (1968) Studies on the life of the common myna, Acridotheres tristis (Linnaeus) [Aves: Passeriformes: Sturnidae]. Proc. Zool. Soc. Calcutta, 21, 1-27.

Appendix C. Floral Species Diversity on FV and MV farms in Wet Season (July - September)

\begin{tabular}{|c|c|c|c|}
\hline Species & Status & FV (No herbicide) & MV(Treated with herbicide) \\
\hline \multicolumn{4}{|l|}{ Graminae } \\
\hline Cyperus rotundus & Wild & + & + \\
\hline Setaria viridis & Wld & + & + \\
\hline Eragrostis unioloides & Wild & + & + \\
\hline \multicolumn{4}{|l|}{ Amaranthaceae } \\
\hline Alternanthera sessilis & Wild & + & - \\
\hline \multicolumn{4}{|l|}{ Asteriaceae } \\
\hline Enhydra fluctuens & Wild & + & - \\
\hline \multicolumn{4}{|l|}{ Scrophulariaceae } \\
\hline Bacopa monnieri & Wild & + & - \\
\hline \multicolumn{4}{|l|}{ Chenopodiaceae } \\
\hline Chenopodium album & Wild & + & + \\
\hline \multicolumn{4}{|l|}{ Rubiaceae } \\
\hline Ludwigia parviflora & Wild & + & - \\
\hline \multicolumn{4}{|l|}{ Marsiliaceae } \\
\hline Marsilea minuta & Wild & + & - \\
\hline \multicolumn{4}{|l|}{ Asclepiadaceae } \\
\hline Calotropis procera & Planted & + & - \\
\hline \multicolumn{4}{|l|}{ Fabaceae } \\
\hline Cajanus cajan & Cultivated & + & - \\
\hline Phaseolus mungo & Cultivated & + & - \\
\hline Vigna sinensis & Cultivated & + & - \\
\hline Aeschynomene indica & Wild & + & - \\
\hline
\end{tabular}

\section{REFERENCES}

Aulakh, MS, Khera, TS, Doran, JW, Singh, K, \& Singh, B (2000) Yields and nitrogen dynamics in a rice-wheat system using green manure and inorganic fertilizer. Soil Science Society of America Journal, $64,1867-76$

Bascompte, J. \& Melian, CJ (2005) Simple trophic modules for complex food webs. Ecology, 86, 2868-2873.

Bersier, L.-F \& Sugihara, G (1997) Scaling regions for food web properties. Proceedings of the National Academy of Science USA, 94, 12471251.

BESG (Bird Ecology Study Group) (2009) < http://besgroup.talfrynature. com/category/feeding-invertebrates $>$

Borrvall, C, Ebenman, B \& Jonsson, T (2000) Biodiversity lessens the risk of cascading extinction in model food webs, Ecoogival Letters, 3, $131-136$.
Briand, F \& Cohen, J E (1984) Community food webs have scale invariant structure. Nature 307, 264-267.

Bruno, JF and Cardinale, BJ (2008) Cascading effects of predator richness. Frontiers in Ecology and Environment, 6, 539-546.

Byrnes, J, Stachowitz, J, Hultgren, KM, Hughes, AR, Olyarnik, SV \& Thornber, CS (2006) Predator diversity strengthens trophic cascades in kelp forests by modifying herbivore behavior. Ecological Letters, 9, 61-71.

Clawson, DL (1985) Harvest security and intraspecific diversity in traditional tropical agriculture. Economic Botany 39, 56-67.

Chen, Y (2008) The unsung heroes of the rice field. Rice Today 30-31.

Cohen JE, Briand, F \& Newman, CM (1990) Community Food Webs: Data and Theory. Springer: New York.

Coll, M \& Guershon, M (2002) Omnivory in terrestrial arthropods: mixing plant and prey diets. Annual Review of Entomology, 47, 267-97.

Costa, MJ, Monteiro, DA, Oliveira-Neto, AL, Rantin, FT \& Kalinin, AL (2008) Oxidative stress biomarkers and heart function in bullfrog 
tadpoles exposed to Roundup Original ${ }^{\circledR}$. Ecotoxicology, 17, 153163.

Daniel, J C (1983) The Book of Indian Reptiles. Bombay Natural History Society: Bombay.

Deb, D (1995) Scale-dependence of food web structure: Tropical ponds as paradigm. Oikos, 72, 245-262.

Deb, D (1997) Trophic uncertainty and parsimony in food web research. Oikos, 78, 191-194.

Deb, D (2004) Industrial vs Ecological Agriculture. Research Foundation for Science Technology \& Ecology: New Delhi.

Denno, RF, Mitter, MS, Langellotto, GA, Gratton, C \& Finke, DL (2004) Interactions between a hunting spider and a web-builder: consequences of intraguild predation and cannibalism for prey suppression. Ecological Entomology, 29, 566-577.

Deuti, K \& Bharati Goswami, BC (1995) Amphibians of West Bengal Plains. WWF-India Eastern Region: Calcutta.

Duffy, JE, Cardinale, BJ, France, KE, McIntyre, PB, Thébault, E \& Loreau, M (2007) The functional role of biodiversity in ecosystems: incorporating trophic complexity. Ecology Letters, 10, 522-538.

Dunne, JA, Williams, RJ \& Martinez, ND (2002) Network structure and biodiversity loss in food webs: robustness increases with connectance. Ecology Letters, 5, 558-567.

Dunne, JA, Williams, RJ \& Martinez, ND (2004) Network structure and robustness of marine food webs. Marine Ecology Progress Ser. 273, 291-302.

Dwivedi, J L (1997) In: Sperling, L \& Loevinsohn, M (Eds), Enhancing and Maintaining Genetic Resources On-Farm, IDRC. URL: $<$ http://archive.idrc.ca/library/document/104582/dwivedi.html>

FAO (1997) The State of the World's Plant Genetic Resources for Food and Agriculture. Food and Agriculture Organization of the United Nations, Rome

Finke, DL \& Denno, RF (2005) Predator diversity and the functioning of ecosystems: the role of intraguild predation in dampening trophic cascades. Ecology Letters, 8, 1299-1306.

Fussmann, GF \& Heber, G (2002) Food web complexity and chaotic population dynamics. Ecology Letters, 5, 394-401.

Gill GS (1995) Package of Practices for Kharif (summer) and Rabi (winter) Crops. Directorate of Extension Education, Punjab Agricultural University: Ludhiana, India.

Goldwasser, L \& Roughgarden, J (1993) Construction and analysis of a large Caribbean food web. Ecology, 74, 1216-1233.

Grimmet, R, Inskipp, C \& Inskipp, T (1998) Birds of the Indian Subcontinent. Oxford University Press: Delhi.

Gunnarsson, B (2008) Bird predation on spiders: ecological mechanisms and evolutionary consequences. Journal of Arachnology, 35, 509529.

Heong, KL \& Schoenly, KG (1998) Impacts of insecticides on herbivorenatural enemy communities in tropical rice ecosystem. In: Haskell, PT, McEwen, P (Eds), Ecotoxicology: Pesticides and Beneficial Organisms. Dordrecth, Netherlands: Kluwer pp. 381-403.

Heong, KL, Manza, A, Catindig, J, Villareal S \& Jacobsen, T (2007) Changes in pesticide use and arthropod biodiversity in the IRRI research farm. Outlooks on Pest Management, 1-5.

Hooper, DU, Chapin, III, F S, Ewel, J J, Hector, A, Inchausti, P, Lavorel, S, Lawton, J H, Lodge, D M, Loreau, M, Naeem, S, Schmid, B, Setälä, H, Symstad, A J, Vandermeer, J \& Wardle, DA (2005) Effects of biodiversity on ecosystem functioning: a consensus of current knowledge. Ecological Monographs, 75, 3-35.

Hossain, M \& Narciso, J (2004) Global rice economy, long term perspectives. Paper presented in the FAO Conference, " Rice in Global Markets and Sustainable Production Systems" held in Rome on 12-13 February, 2004 to celebrate the International Year of Rice 2004. http://www.fao.org/docrep/008/a0033e/a0033e04.htm

Katano, O, Nakamura, T \& Yamamoto, S (2006) Intraguild indirect effects through trophic cascades between stream-dwelling fishes. Journal of Animal Ecology, 75, 167-175.

Kinzig, A, Pacala, SW \& Tilman D (2002) Functional Consequences of Biodiversity: Empirical Progress and Theoretical Extensions. Princeton University Press: Princeton.

Leakey, RRB (1999) Agroforestry for biodiversity in farming systems. In: Collins WW and Qualset CO (Eds.), 127-146, Biodiversity in Agroecosystems, CRC Press: Boca Raton.

Letourneau, DK \& Bothwell, SG (2008) Comparison of organic and conventional farms: challenging ecologists to make biodiversity functional. Frontiers in Ecology and the Environment, 6, 70-81.
McCann, K \& Hastings, A (1997) Re-evaluating the omnivory-stability relationship in food webs. Proceedings of the Royal Society B 264, 1249-1254.

Maeda, T. (2001). Patterns of bird abundance and habitat use in rice fields of the Kanto Plain, central Japan. Ecological Research 16: 569585.

Mäder, P, Fließbach, A, Dubois, D, Gunst, L, Fried, P \& Niggli, U (2002) Soil fertility and biodiversity in organic farming. Science, 296, 1694-1697.

Martinez, ND (1992) Constant connectance in community food webs. American Naturalist, 139, 1208-1218.

Martinez, ND (1993) Effects of resolution on food web structure. Oikos, 66, 403-412.

Martinez, ND, Williams, RJ \& Dunne, JA (2005) In: Pascual, M \& Dunne, JA (Eds.), Ecological Networks: Linking Structure to Dynamics in Food Webs, Oxford: Oxford University Press 163-185.

Matson, PA, Parton, WJ, Power, AG \& Swift, MJ (1997) Agricultural intensification and ecosystem properties. Science, 277, 504-509.

Memmott, JD, Alonso, EL, Berlow, A, Dobson, JA, Dunne, R Solé (2005) In: Weitz, J, Pascual, M \& Dunne, JA (Eds), Ecological Networks: Linking Structure to Dynamics in Food Webs. Oxford, University Press: Oxford 325-347.

Monsanto Company (2009) Weed Control. Note on usage of Roundup $\AA$ Original. URL: http://www.monsanto.ca/weed_control/product use/preplant.asp

Paine, RT (2004) Virtual ecosystems. Conservation in Practice, 5(1), 39.

Paoletti, MG, Dunxiao, H, Marc, P, Ningxing, H, Wenliang, W, Chunru, H, Jiahai, H \& Liewan, C (1999) Arthropods as bioindicators in agroecosystems of Jiang Han Plain, Qianjiang City, Hubei China. Critical Reviews in Plant Sciences, 18, 457-465.

Pearson, CJ (2007) Regenerative, semiclosed systems: a priority for twentyfirst-century agriculture. BioScience 57: 409-418.

Philpott, SM, Greenberg, R, Bichier, P \& Perfecto, I (2004) Impacts of major predators on tropical agroforest arthropods: comparisons within and across taxa. Oecologia, 140, 140-149.

Pimentel, D, Hepperly, P, Hanson, J, Douds, D \& Seidel, R (2005) Environmental, energetic, and economic comparisons of organic and conventional farming systems. BioScience 55, pp. 573-582.

Pimm, SL (1997) In search of perennial solutions. Nature 389, pp. 126-127.

Pimm, SL (2002) Food Webs, 2nd ed, London Chapman \& Hall.

Polis, GA (1991) Complex trophic interactions in deserts: an empirical critique of food-web theory. Ameican Naturalist, 138, 123-155.

Polis, GA \& Strong, DR (1996) Food web complexity and community dynamics. American Naturalist, 147, 813- 846.

Post, DM (2002) The long and short of food-chain length. Trends in Ecology and Evolution 17, 269-277.

Prater, W (1988) The Book of Indian Animals, Bombay Natural History Society: Bombay.

Reagan, DP, Camilo, GR \& Waide, RB (1996) In: Reagan, DP \& Waide, RB (Eds) The Food Web of a Tropical Rain Forest. Chicago: University of Chicago Press, 461-510.

Relyea, RA (2005) The lethal impact of roundup on aquatic and terrestrial amphibians. Ecological Applications, 15, 1118-1124.

Relyea, RA (2006) The impact of insecticides and herbicides on the biodiversity and productivity of aquatic communities. Ecological Applications, 16, 2022-2027.

Riechert, SE (1999) The hows and whys of successful pest suppression by spiders: insights from case studies. Journal of Arachnology, 27, 387-396

Rosenheim, JA \& Corbett, A (2003) Omnivory and the indeterminacy of predator function: can a knowledge of foraging behavior help? Ecology, 84, 2538-2548

Sathiamma, B (1995) Biological suppression of the white spider mite Oligonychus iseilemae (Hirst) on coconut foliage. Entomon, 20, 237-243.

Settle, WH, Ariawan, H, Astuti, ET, Cahyana, W, Hakim, AL, Hindayana, D \& Lestari, AS (1996) Managing tropical rice pests through conservation of generalist natural enemies and alternative prey. Ecology, 77, 1975-1988.

Schmitz, OJ (2007) Predator diversity and trophic interactions. Ecology, 88, 2415-26.

Schoenly, K., Mew, TW \& Reichardt, W (1998) In: Dowling, NG, Greenfield, SM \& Fischer, KS (Eds) Sustainability of Rice in the Global Food System. Manila, Pacific Basin Studies Center/IRRI 285-299. 
Stark, JD \& Banks, JE (2002) Population-level effects of pesticides and other toxicants on arthropods. Annual Review of Entomology 48, 505-519.

Stewart, M and Woolbright LL (1996) In: Reagan, Douglas P and Waide RB (Eds), The Food Web of a Tropical Rain Forest. Chicago: University of Chicago Press 273-320.

Takimoto, G, Spiller, DA \& Post, DM (2008) Ecosystem size, but not disturbance, determines food-chain length on islands of the Bahamas. Ecology, 89, 3001-3007.

Tscharntke, T, Klein, AM, Kruess, A, Steffan-Dewenter, I \& Thies, C (2005) Landscape perspectives on agricultural intensification and biodiversity ecosystem service management. Ecology Letters, 8, 857-874.

Tilman, D (1998) The greening of the green revolution. Nature 396, pp. 211-212.

Tilman, D, Cassman, KG, Matson, PA, Naylor, R and Polasky, S (2002) Agricultural sustainability and intensive production practices. Nature 418, 671-677.
Tilman, D, Reich, PB and Knops, JMH (2006) Biodiversity and ecosystem stability in a decade-long grassland experiment. Nature 441, 629632.

Van Bael, SA, Philpott, S M, Greenberg, R, Bichier, P, Barber, NA, Mooney, KA \& Gruner, DS (2008) Birds as predators in tropical agroforestry systems. Ecology, 89, 928-934.

Venkatesha, MG (2005) Why is homopterophagous butterfly, Spalgis epius (Westwood) (Lepidoptera: Lycaenidae) amyrmecophilous? Current Science 89 (2): 245-246.

Whitaker, R \& Captain, A (2004) Snakes of India: The Field Guide. Chennai. Draco Books.

Wilby, A, Villareal, SC, Lan LP, Heong, KL and Thomas, MB (2005) Functional bvenefits of predator species diversity depend on prey identity. Ecological Entomology, 30, 497-501.

Williams, RJ \& Martinez, ND (2004) Limits to trophic similarity and omnivory in complex food webs: theory and data. American Naturalist, 163, 458-468.

Worm, B \& Duffy, JE (2003) Biodiversity, productivity and stability in real food webs. Trends in Ecology and Evolution, 18, 628-632. 